\title{
Yükseköğretimde İnsani Becerilerin Öğrenenlere Kazandırılması İçin Öz Yönelimli Öğrenme Modeli
}

\author{
DOI: $10.26466 /$ opus.595168
}

\author{
Hüseyin Şimşek* - Elif İlhan** \\ * Doç. Dr, Kırşehir Ahi Evran Üniversitesi, Eğitim Fakültesi, Kırşehir / Türkiye \\ E-Posta: husimsek@hotmail.com ORCID: 0000-0001-7455-3706 \\ ** Dr., Ankara Hacı Bayram Veli Üniversitesi Yabancı Diller Y.O Ankara / Türkiye \\ E-Posta: elif igrek@hotmail.com \\ ORCID: 0000-0002-8536-1571
}

Öz

Yükseköğretim kurumlarından, hızla değişen sosyal ve mesleki koşullara uyum sağlayabilecek niteliklere sahip bireyler yetiştirmesi beklenmektedir. Bu nitelikler, mesleki becerilerle birlikte insani becerileri de kapsamaktadır. Insani beceriler, belirli bir disipline/mesleğe özgü olmayan genel becerilerdir. Insani becerilerin yükseköğretimde öğrenenlere kazandırılmasında etkili olabilecek öğrenme modellerinden birisi öz yönelimli öğrenmedir. Bu modelde, öğrenenlerin öğrenme sürecinin bütün aşamalarında etkin olarak mesleki bilgi ve becerilerin yanı sıra insani beceriler de kazanması beklenmektedir. Bu araştırmanın amacı, yükseköğretimde öğrenenlere kazandırılması beklenen insani becerileri belirlemek ve öz yönelimli öğrenme modelinin onların kazandırılmasında etkililiğini tartışmaktır. Araştırma, bir geleneksel derleme araştırmasıdır. Araştırma kapsamında, öğrenenlere kazandırılması beklenen insani beceriler ve öz yönelimli öğrenme modelinin temel özellikleri, bu modelin yükseköğretimde kullanılmasının uygunluğu ve insani becerilerin kazandırılmasındaki etkililiği tartışılmıs, insani becerilerin kazanılmasında uygulanabilecek döngüsel bir öz yönelimli öğrenme modeli geliştirilmiştir. Araştırma sonuçları temel alınarak, insani becerilerin öğrenenlere kazandırılmasının yükseköğretimde uygulanan programların hedefleri arasına dâhil edilmesi, yükseköğretimde lisans/lisansüstü düzeylerdeki araştırma-uygulama odakl derslerde öz yönelimli öğrenme modelinden ve bu araştırmada geliştirilen döngüsel öz yönelimli öğrenme modelinden faydalanilması önerilmektedir.

Anahtar Kelimeler: Yükseköğretim, İnsani beceriler, Öz yönelimli öğrenme modeli, Geleneksel derleme araştırması 


\title{
Self-Directed Learning Model to Obtain Learners Soft Skills at Higher Education
}

\begin{abstract}
Higher education institutions are expected to train individuals with qualifications to adapt to rapidly changing social-professional conditions. These qualifications include soft skills besides professional skills. Soft skills are general skills which are not specific to any discipline/profession. Self-directed learning model can be effective in helping learners acquire soft skills at higher education level. Because learners are always active in the learning process in this model, they can easily acquire soft skills besides various professional knowledge and skills. This study aims to determine soft skills expected to be acquired by learners at higher education and to discuss the effectiveness of the self-directed learning model in acquiring soft skills. The study is a traditional review study. Within the scope of the study, basic features of soft skills and the way they are acquired by learners at higher education are discussed. It is also argued about self-directed learning model and its suitability/ effectiveness in acquiring soft skills. Lastly, a curricular self-directed learning model that can be applied in acquiring soft skills has been developed. Based on the results of the study, it is suggested that the acquirement of soft skills by learners be included in the objectives of the curricula at higher education and also that self-directed learning model and the circular self-directed learning model developed in this study be applied in research/application-oriented courses at undergraduate / graduate levels of higher education.
\end{abstract}

Keywords: Higher education, Soft skills, Self-directed learning model, Traditional review study 


\section{Giriş}

Yükseköğretim kurumlarından, yaşamın her alanında -akademik, sosyal ve mesleki- başarılı bireyler yetiştirmesi beklenmektedir. Bu beklentiyi karşılamanın temel yollarından biri yenilikçi eğitim programları aracılığıyla sağlanabilecek olan etkili öğrenme-öğretme faaliyetleridir (Salmi, 2009 , s.71). Ancak yükseköğretim kurumlarında sağlanan bu tür faaliyetlerin verimsizliğine ve öğrenenlerin kendilerinden beklenen niteliklere sahip olmadan mezun olduğuna ilişkin eleştiriler devam etmektedir. Bu eleştiriler bazı araştırma sonuçları ile de desteklenmektedir (Arum ve Roksa, 2011; ChangeWorks, Inc., 2006; CEDA, 2015, s.55; Harvey, Geall, ve Moon, 1997; Kantek, Öztürk ve Gezer, 2010; Leveson, 2000; Mourshed, Farrel ve Barton, 2012; Saracaloğlu, Yenice ve Karasakaloğlu, 2009; OECD, 2016, s.26; Programme for the International Assessment of Adult Competencies, 2016; The Conference Board, Inc., the Partnership for 21st Century Skills, Corporate Voices for Working Families, and the Society for Human Resource Management, 2006).

Yukarıda belirtilen araştırmalardan bazıları özellikle yükseköğretim kurumlarının öğrenenleri mesleki yaşamda başarılı bireyler olarak yetiştirme görevine ilişkin sorunların yaşandığını göstermektedir. Örneğin Mourshed, Farrel ve Barton (2012) tarafından 24 farklı ülkedeki gerçekleştirilen kapsamlı bir araştırmada görüşleri alınan öğretim elemanlarının \%72'si öğrenenlerin hedeflenen niteliklere sahip olduğunu savunurken; işverenlerin \%58'i bunun tam tersini iddia etmiştir. Jaschik (2015) tarafından yapılan bir başka araştırmada ise işverenler üniversite mezunlarını, üniversite mezunları ise kendilerini hedeflenen niteliklere sahip olma durumuna göre değerlendirmiş, işverenlerin öğrenenlere verdiği puanların, öğrenenlerin kendilerine verdiği puanlardan daha düşük olduğu rapor edilmiştir. Ayrıca araştırma kapsamına dâhil edilen her bir beceriye ilişkin değerlendirme puanlarında en az \%30'luk bir sapma olduğu belirlenmiştir. Bu sonuçlar; yükseköğretimde öğrenenlere kazandırılan ile işverenlerin onlardan beklediği nitelikler arasında önemli farklar olduğunu göstermektedir.

Yükseköğretimde öğrenenlerin kazanması beklenen niteliklerin neler olması gerektiğine ilişkin çalışmalar incelendiğinde bu niteliklerin belirli 
başlıklar altında toplandığı görülmektedir. Puncreobutr (2016) bu becerileri 21. yy becerileri, hayat boyu öğrenme becerileri, yaşam becerileri, yenilik becerileri şeklinde tanımlarken, Gewertz (2007) uygulama becerileri olarak tanımlamıştır. Johnston ve McGregor (2004) teknik olmayan beceriler, genel beceriler şeklinde sınıflandırırken, Kechagias (2011) bunları çekirdek beceriler, anahtar yeterlilikler veya insani beceriler (soft skills) şeklinde sınıflandırmıştır. Yerli alanyazında ise bu beceriler ilk kez İlhan, Kalaycı ve Demir (2018) insani beceriler olarak adlandırmıştır. Bu araştırmada da, farklı biçimlerde tanımlanan bu niteliklerin adlandırılmasında "insani beceriler" kavramının kullanılması tercih edilmiştir. İnsani beceriler, belirli bir alana, mesleğe özgü olmayan; genel becerilerdir. Bu kavram için kabul edilen genel bir tanım yoktur (Taylor, 2016). Her bir disiplin, eğitim alanı hatta ülkenin kültürel özellikleri ve ihtiyaçlarına göre farklı tanımlar yapılmıştır (Kechagias, 2011). Tanımlamalardaki farklılığa rağmen, bu genel becerilerin önemi ve yükseköğretimde öğrenenlere kazandırılmasının gerekliliği konusunda büyük bir uzlaşma sağlanmıştır (Bancino ve Zevalkink, 2007; Gibb, 2014; Grisi, 2014; Kechagias, 2011; Klaus, 2010; Robles, 2012). Ancak alanyazın incelendiğinde, insani becerilerin nasıl kazandırılacağına ilişkin araştırmaların sınırlı ve bu konudaki görüşlerin birbirinden farklı olduğu görülmektedir (Adomssent vd., 2007; Taylor, 2016).

Alanyazında belirlenen bu sınırlılıklar ve görüş birliğinin olmaması; yükseköğretimde insani becerilerin öğrenenlere kazandırılmasında etkili model ve yöntemlerin neler olabileceğine ilişkin tartışmaların önemini artırmaktadır. İnsani becerilerin öğrenenlere kazandırılması; teorik bir konu olmayıp, öğrenenlerin öğrenme sürecine aktif katılımını gerektiren uygulamaya dönük bir özellik taşımaktadır. Bu becerilerin öğrenenlere kazandırılmasında asıl odaklanılması gereken konu, öğrenenlerin, öğrenme sürecinin bütün aşamalarında aktif katılımını sürdürmesi ve öğrenme sorumluluğunu almasıdır. Gerek öğrenme hedefinin belirlenmesinde gerekse öğrenmenin planlanma, uygulanma ve değerlendirilme sürecinde öğrenenin etkin rol alması beklenmektedir. Bu tür bir öğrenme modeli, öz-yönelimli öğrenme olarak nitelendirilebilir. Bu modelde, öğrenenler öğrenme girişiminde bulunmakta, kendi öğrenme sürecini yönlendir- 
mekte ve sonuçlandırmaktadır. Öz yönelimli öğrenme, öğrenenlerin gereksinim duyduğu pek çok bilgi, beceri ve tutumu kazanmalarında etkili olan bir öğrenme modelidir.

Bu modele ilişkin çalışmalar 20. yüzyılın sonuna doğru artış göstermiştir. Ancak Eker (2014) tarafından da vurgulandığı gibi öz yönelimli öğrenmeye ilişkin yerli ve yabancı alanyazında yapılan çalışmaların büyük bir bölümünde farklı değişkenlerin öz-düzenlemeli öğrenmeye etkisi ve/veya öz yönelimli öğrenmenin akademik başarı ile ilişkisinin incelendiği görülmektedir. Ayrıca yerli alanyazında öğrenenlerin öz yönelimli öğrenmeye hazırbulunuşluk düzeyini (Ör: Aşkın, 2015; Hürsen, 2016; Karataş, 2017; Sarmasoğlu ve Görgülü, 2014) belirlemeye odaklanan çalışmaların da fazla olduğu görülmektedir. Ancak öz yönelimli öğrenme modelinin yükseköğretimde nasıl uygulanabileceğine ilişkin çalışmaların sayısı oldukça azdır. Yabancı alanyazında ise öz yönelimli öğrenme ile akademik başarı arasındaki ilişkinin incelendiği bir araştırmada insani beceriler de akademik başarının bilişsel olmayan bir ögesi olarak kabul edilmiştir (Laskey ve Hetzel, 2010). Bu bağlamda ilgili araştırmada yükseköğretim bağlamında öz yönelimli öğrenme ve insani beceriler ilişkilendirilerek alanyazına katkı sağlayacağı düşünülmektedir.

$\mathrm{Bu}$ araştırmada; insani beceriler, öz yönelimli öğrenme modeli ve bu modelin uygulanma sürecine ilişkin ayrıntılı açıklama ve öneriler sunulmuştur. Yukarıda açıklandığı gibi yükseköğretimde öğrenenlerin kazanması beklenen insani becerilerin neler olduğuna ilişkin alanyazında görüş birliği tespit edilememiştir. Bu araştırma ilgili çalışmaları sentezleyip özetleyerek bu becerilerin neler olduğuna açıklı getirmesi açısından önemlidir. Ayrıca bu becerilerin öğrenenlere nasıl kazandırılacağına ilişkin de uygulamaya dönük öneriler sunduğundan araştırma önem taş1maktadır. Bu araştırmada, yapılan kapsamlı alanyazın taraması sonucunda yükseköğretimde öğrenenlere insani becerilerin kazandırılmasında etkili olabilecek öğrenme modellerinden birinin öz yönelimli öğrenme modeli olduğu görüşü savunulmaktadır. Bu görüşü desteklemek amacıyla öz yönelimli öğrenme modeline ve bu modelin nasıl uygulanacağına ilişkin açıklama/öneriler sunulmuştur. Bu modelin uygulanmasına ilişkin yapılan incelemeler sonucunda, araştırmacılar tarafından belirlenen bazı sınırlılıklar/eksikliklerin giderilmesinde etkili olabileceği düşünülen dön- 
güsel bir öz yönelimli öğrenme modeli geliştirilmiştir. Sunulan bu döngüsel modelin, özellikle yükseköğretimde öğrenenlerin hem insani becerileri hem de diğer bilgi, beceri ve değerleri kazanmasında etkili olabileceği düşünülmektedir. Bu nedenlerle bu araştırma hem yükseköğretimde sunulan eğitimin niteliğini artırma konusunda hem de yükseköğretim kurumlarının "öğrenenlere insani becerileri kazandıramadığı" yönündeki eleştirilerin ortadan kaldırılmasında önemli bir destek sağlayabilir. Böylece alanyazında önemli bir eksiklik olarak hissedilen temel bir soruna ilişkin tartışma başlatarak, araştırmacıların katkı sağlamasına fırsat sunabilir.

\section{Araştırmanın Amacı}

$\mathrm{Bu}$ araştırmanın amacı, yükseköğretimde öğrenenlere kazandırılması beklenen insani becerileri belirlemek ve insani becerilerin kazandırılmasinda etkili olabilecek öz yönelimli öğrenme modelinin etkililiğini tartışmaktır. Bu amaçla, araştırma üç temel başlık çerçevesinde yapılandırılmiştır:

1. İnsani beceriler ve yükseköğretimde öğrenenlere kazandırılması

2. Öz yönelimli öğrenme modeli ve yükseköğretimde uygulanması

3. Öz yönelimli öğrenme modelinin yükseköğretimde öğrenenlere insani becerilerin kazandırılmasında etkililiği

\section{Araştırmanın Yöntemi}

$\mathrm{Bu}$ araştırma, geleneksel derleme türünde bir araştırmadır. Araştırmada, yükseköğretimde öğrenenlere kazandırılması beklenen insani beceriler, öz yönelimli öğrenme modeli ve bu modelin insani becerilerin yükseköğretimde öğrenenlere kazandırılmasında etkililiği ayrıntılı bir şekilde tartışılmıştır. Bu temel konular doğrultusunda doküman analizi yapılmıştır. $\mathrm{Bu}$ veri toplama ve analiz sürecinde, Pautasso (2013) tarafından önerilen işlem basamakları izlenmiştir:

Konunun belirlenmesi: $\mathrm{Bu}$ araştırmada, insani beceriler ve bu becerilerin öğrenenlere kazandırılmasında etkili olabileceği öngörülen öz yönelimli öğrenme konuları temel alınmıştır. 
Alan yazının taranması: Konu ile ilgili öncelikle yerli alanyazın taranmıştır. Yerli alan yazın taranırken "temel nitelikler, temel beceriler, insani beceriler ile öz yönelimli öğrenme, öz yönetimli öğrenme, öz düzenlemeli öğrenme" gibi kavramlar kullanılmıştır. Bu tarama sonucunda yerli alanyazında insani beceriler kavramı ile ilgili bir çalışmaya rastlanmamış, temel beceriler kavramına ilişkin ise bazı çalışmalara ulaşılmıştır. Yerli alanyazında "öz yönelimli öğrenme, öz yönetimli öğrenme, öz düzenlemeli öğrenme" kavramları ile ilgili ise pek çok çalışmaya ulaşılmıştır. Ancak bu çalışmaların büyük çoğunluğunda kişilerin öz yönelimli öğrenmeye hazırbulunuşuluk düzeyini (Ör: Aşkın, 2015; Hürsen, 2016; Karataş, 2017; Orakçı ve Gelişli, 2019; Sarmasoğlu ve Görgülü, 2014) veya öz yönelimli öğrenmenin akademik başarıya etkisini (Ör: Arsal1, 2009; Canca, 2005; Demircan, 2014; Üstün, 2012; Vardar, 2011) belirlemeye odaklanıldı̆̆ı görülmektedir. Yabancı alanyazın taranırken ise "skills, soft skills, self directed learning, self regulated learning" gibi kavramlar kullanılmıştır. Yabancı alanyazında bu kavramlara ilişkin oldukça fazla çalışmaya ulaşılmıştır. Ancak insani becerilerin öğrenenlere kazandırılması için öz yönelimli öğrenme modelinin yükseköğretim bağlamında uygulanmasına ilişkin yerli alanyazında herhangi bir çalışmaya ulaşılamamıştır. Yabancı alanyazında ise öz yönelimli öğrenme ile akademik başarının ilişkisinin incelendiği yalnızca bir araştırmaya ulaşılmıştır (Laskey ve Hetzel, 2010). İyi bir derleme araştırmasında; araştırma sorularına yanıt alabilmek için kapsamlı bir alan yazın taraması ve olabildiğince farklı kaynaktan bulunan çalışmaların nitelik açısından değerlendirilmesini gerekmektedir (Gülpınar ve Güçlü, 2013). Bu araştırmada da veri kaynağı olarak Proquest ve YÖK tez veri tabanında bulunan lisansüstü tezler, uluslararası ve ulusal indekslerde taranan hakemli dergilerde yayınlanmış yaklaşık 100 nitelikli makale, bildiri ve kitap kullanılarak kapsamlı bir alan yazın taraması yapılmiştır.

Okuma sırasında notlar alınması: Yapılan taramalar sonucunda ulaşılan çalışmalar sınıflandırılmış, konu ile ilgili olduğu değerlendirilenler analiz edilerek notlar alınmış, ulaşılan veriler özetlenmiş ve tablolar hazırlanmiştır. 
Yazılmak istenen derleme türüne karar verilmesi: Derleme araştırmaları, müdahaleci (interventionist) ve geleneksel (traditional/scholastic) olmak üzere ikiye ayrılmaktadır (Hart, 2018). Bu araştırmada; alanyazında ilgili çalışmaları incelemek, değerlendirmek ve kavramsal analiz aracılığıyla çıkarım yapmak amaçlandığından, geleneksel (traditional/scholastic) derleme türü tercih edilmiştir (Greenhalgh, Thorne ve Malterud, 2018; Hart, 2018).

Derlemenin insanların ilgisini çekecek bir konuya odaklanması: Araştırmada, son zamanlarda bireylere kazandırılmasının gerekliliği daha sık vurgulanan insani beceriler ve bu becerilerin kazandırılması etkili olduğu düşünülen öz yönelimli öğrenme modeline odaklanılmaktadır. Bu nedenle bu araştırma hem alanyazına hem de özellikle yükseköğretimde eğitimin niteliğini artırmaya yönelik politikalar ve uygulamalar geliştirilme sürecine katkı sağlayacaktır.

Eleştirel ve tutarlı bir tavır sergilenmesi: Alanyazın taramasında ulaşılan kaynakların niteliği ve odaklanılan konuyla bağlantısı dikkate alınarak, farklı görüşlerin tartışılmasına ve konuyla ilişki kurulmasına çaba gösterilmiştir.

Mantıklı bir yapının kurulması: Alanyazın taraması ve analizler sonucunda elde edilen veriler, araştırma soruları doğrultusunda yapılandırılarak açıklanmıştır.

Geri bildirimlerin göz önünde bulundurulması: Araştırmada tutarsızlık ve karmaşıklık olup olmadığını belirlemek ve gerekli düzeltmeleri yapmak için eğitim programları ve öğretim alanından iki farklı uzmandan görüş alınmıştır.

Konuya ilişkin araştırmacılara ait çalışmaların tarafsız bir şekilde derlemeye dahil edilmesi: Araştırmada ilgili pek çok araştırmaya yer verilmiş, ancak araştırmacıların derlemeye dahil edilen herhangi bir çalışması olmamıştır. 
Güncel çalışmalara yer verilmesi: İlgili güncel çalışmalara öncelik verilmesine özen gösterilmiş, ancak bu konudaki öncü çalışmalar da araştırmaya dâhil edilmiştir.

$\mathrm{Bu}$ araştırmada konuya ilişkin yüzden fazla sayıda nitelikli kaynaktan faydalanılarak (Miles ve Huberman, 1994) bir mantıki sıralama/yapı oluşturulması (Yıldırım ve Şimşek, 2013) araştırmanın inandırıcılığına katkı sağlamaktadır. Ayrıca araştırmanın genel yapısı, çalışma çerçevesinde geliştirilen “Öz yönelimli öğrenme sürecinin döngüsel gösterimi ve işlem basamakları (Şekil 1)" ve "Öz yönelimli öğrenme modelinin yükseköğretimde öğrenenlere insani becerilerin kazandırılmasında etkililiğinin" tartışıldığı bölüme ilişkin eğitim programları ve öğretim alanından iki farklı uzmandan görüş alınmıştır. Bu süreçte uzmanlar tarafından araştırmacılara yöneltilen sorular/eleştiriler, eksiklerin/hataların fark edilmesini ve düzeltilmesini sağlamıştır. Bu süreç araştırmanın inandırıcılığına katkı sağlamıştır (Creswell ve Miller, 2000). Araştırmanın veri toplama ve analiz sürecinde izlenen işlem basamaklarının ayrıntılı şekilde açıklanması ise araştırmanın aktarılabilirliğe katkı sağlamaktadır (Lincoln ve Guba, 1986).

Araştırmanın bu bölümünde yukarıda açıklanan yöntem doğrultusunda kapsamlı bir alanyazın taraması ile elde edilen veriler, üç temel başlik altında sunulmuştur.

\section{İnsani Beceriler (Soft Beceriler) Ve Yükseköğretimde Öğrenenlere Kazandırılması}

\section{Insani Beceriler (Soft Skills)}

İnsani beceriler; somut-teknik olmayan beceriler, kişisel özellikler (Hewitt, 2006; Wilhelm, Logan, Smith, ve Szul, 2002) ve kişiler arası beceriler (Kechagias, 2011) olarak tanımlanmaktadır. Bu beceriler, belirli bir disipline veya mesleğe özgü değildir (Yan, Yinghong, Lui, Whiteside ve Tsey, 2018). Bu özellikleriyle, belirli bir alanda uzmanlaşma için gerekli olduğu belirtilen teknik (hard) becerilerden ayrılmaktadır. Çünkü teknik becerilerin aksine insani beceriler, belirli bir uzmanlık alanın ya da mesleğin gereksinimlerinden daha kapsamlıdır (Grisi, 2014) ve tüm mesleklerin 
başarılı bir şekilde yapılabilmesi için gereksinim duyulan becerileri-kişisel özellikleri kapsamaktadır (Wilhelm vd., 2002).

Son yıllarda, eğitim alanyazınında insani becerilere daha çok vurgu yapılmaya başlanmış, giderek daha fazla sayıda rapor, araştırma ve bilimsel çalışmada insani beceriler konu edinilmiştir. Nussbaum (2010) "Maddi Kazanç için Değil: Demokrasi Neden Beşerî Bilimlere İhtiyaç Duyar?" (Not for Profit: Why Democracy Needs the Humanities) adlı kitabında, insani becerilerin önemine dikkat çekmiş ve eğitimle ilgili yaygın bir düşünceyi şu şekilde eleştirmiştir: "Eğitimin temel amacı, öğrenenlerin ekonomik olarak üretici olmasını sağlamak değildir." Bunun yerine onların eleştirel düşünen, bilgili ve empati kuran bireyler olarak yetiştirilmesi gerekmektedir. Öğrenenlerin mesleki bilgilerin ve teknik becerilerin yanı sıra karşılaştıkları problem çözme, yaratıcılık, takım halinde çalışma ve takımlara liderlik etme, analitik ve soyut düşünme becerilerine sahip olması beklenmektedir (Wynekoop ve Walz, 2000).

Nobel Ödüllü Ekonomist James Heckman, insani becerileri, yaşam başarısının yordayıcısı olarak nitelemiştir (akt. Cinque, 2015). İnsani beceriler, bireyin kendini gerçekleştirme sürecinde sahip olması gereken en temel becerilerdendir (Cinque, 2015). Çünkü insani beceriler; bireylerin sosyal yaşamdaki sorunlara yaratıcı çözümler bulmalarını ve mesleki yaşamlarını daha iyi yönetmelerini sağlamaktadır (Chen 2010; Fullan ve Scott 2014; Gabriel-Petit 2017; Hytti ve O'Gorman 2004; Whiteside et al. 2017; Wiek, Withycombe, ve Redman, 2011). İnsani beceriler; mesleki yaşamda bireylerin etkili iletişim kurmasını, takım çalışmalarında başarılı olmalarını, iş yerine ait kültürel normları kavramalarını ve bunlara kolay uyum sağlamalarına yardımcı olmaktadır (Wilhelm vd., 2002).

Wheeler (2016) teknik becerileri kazandıktan sonra öğrenenlerin kendini geliştirmesi, yükselmesi/daha üst mevkilere gelmesi ve mutlu/başarılı bir yaşam sürmesi için insani becerilere sahip olmalarının şart olduğunu ileri sürmüştür. Sonuç olarak, insani beceriler; akademik (Gibb, 2014), sosyal (Cinque, 2015; Gibb, 2014; Kechagias, 2011; Wheeler, 2016; Wilhelm vd., 2002; Wynekoop ve Walz, 2000) ve mesleki (Cinque, 2015; Gibb, 2014; Kechagias, 2011; Wheeler, 2016; Wilhelm vd., 2002; Wynekoop ve Walz, 2000) başarı için gereklidir.

İlgili alan yazında insani becerilerin neler olduğuna ilişkin çok sayıda bilimsel çalışma ve araştırma bulunmaktadır (Bancino ve Zevalkink, 2007; 
Yükseköğretimde İnsani Becerilerin Öğrenenlere Kazandırılması İçin Öz Yönelimli Öğrenme Modeli

Casner-Lotto ve Barrington, 2006; Hewitt, 2006; National Association of Colleges ve Employers (NACE), 2009; ODEP, 2007; PUCCO, 2002; Skills for College and Career Readiness, 2016). Bu araştırmaların incelenmesi sonucunda insani becerilere ilişkin aşağıdaki tablo oluşturulmuştur:

Tablo 1. Farklı araştırmacılara göre insani beceriler

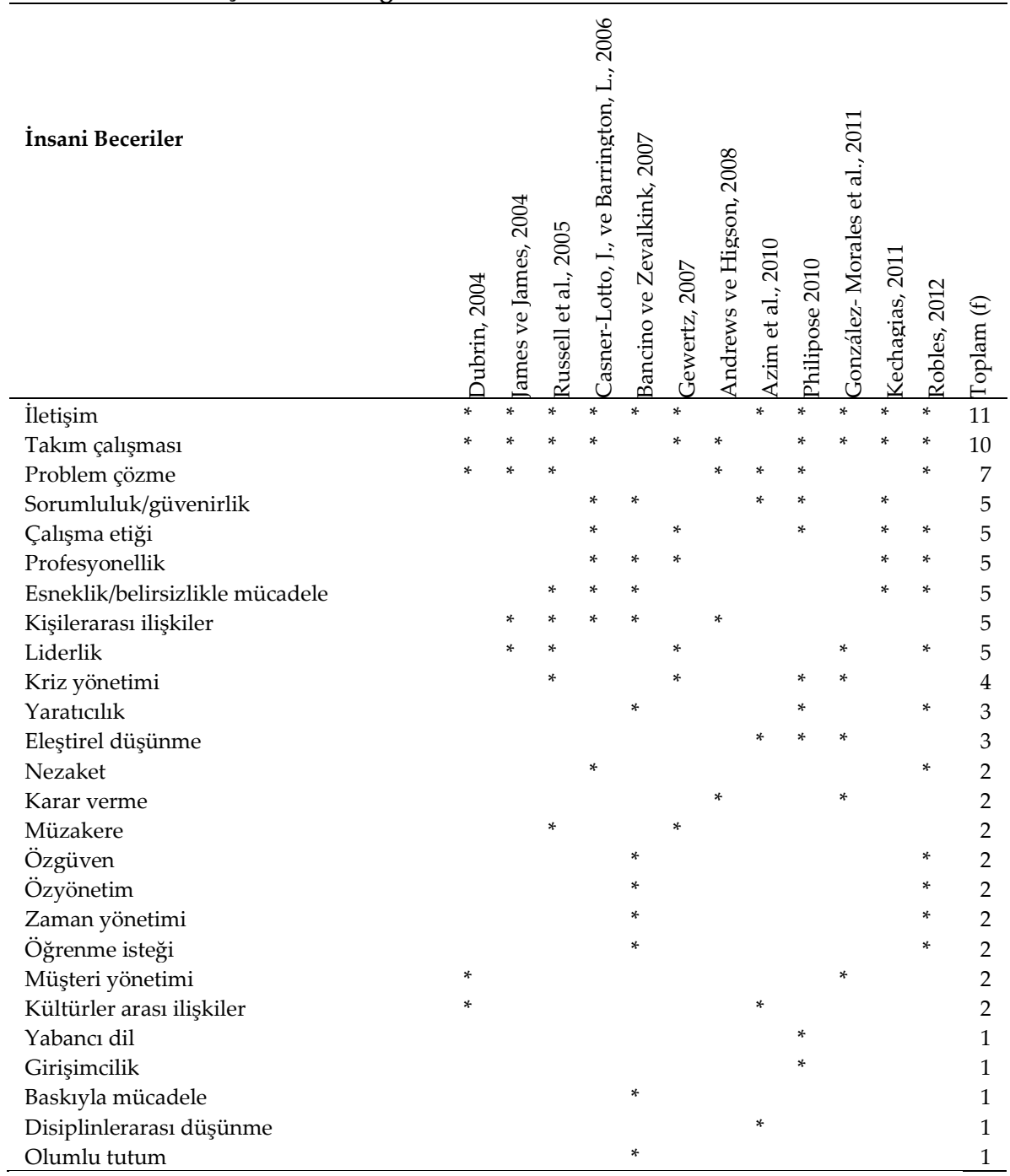

Not: Illhan, Kalaycı ve Demir (2018) tarafından hazırlanan tablonun genişletilmiş halidir. 
Yukarıdaki tabloda görüldüğü gibi, en çok tekrarlanan insani beceriler; iletişim, takım çalışması, problem çözme, sorumluluk/güvenirlik, çalışma etiği, profesyonellik, esneklik/belirsizlikle mücadele, kişilerarası ilişkiler, liderlik ve kriz yönetimidir.

İnsani beceriler, alanyazında çoğunlukla kişisel ve kişilerarası beceriler olmak üzere iki grupta incelenmektedir. Kişisel beceriler; zaman yönetimi, kendini yönetme, hak ve sorumluluklarının farkında olma, öğrenme ve performansını geliştirme ile ilgilidir. Kişilerarası beceriler ise başka kişilerle etkileşim kurulmasında işe koşulan beceri ve tutumlarla ilgilidir (Schulz, 2008). Bir diğer sınıflamada insani beceriler, öğretilebilir olma durumlarına göre iki gruba ayrılmaktadır (Urs-Sorana, 2013). Bunlar geleneksel insani beceriler (yabancı dil yeterliliği, iletişim becerileri, takım çalışması) ve üst düzey (ince) insani becerilerdir (özgüven, özsayg1, dürüstlük ve etik). Tablo 1'e göre en sık vurgulanan insani beceriler kişisel (profesyonellik, esneklik/belirsizlikle mücadele, problem çözme sorumluluk/güvenirlik çalışma etiği ve kriz yönetimi) ve geleneksel (iletişim, takım çalışması, profesyonellik, esneklik/belirsizlikle mücadele, kişilerarası ilişkiler, liderlik, problem çözme ve kriz yönetimi) becerilerdir. Bu becerilerin dikkat çeken ortak özelliği, öğretilebilir insani beceriler olmasıdır. Öte yandan Tablo 1'e göre kişilerarası (iletişim, takım çalışması, liderlik kişilerarası ilişkiler) ve üst düzey (çalışma etiği sorumluluk/güvenirlik) insani beceriler ise nispeten daha az vurgulanmıştır. Urs-Sorana (2013) bu üst düzey insani becerilerin, "öğretilemez" olduğunu; ancak kendini gerçekleştirme sonucunda kazanılabileceğini iddia etmiştir. Üst düzey insani becerilere araştırmacıların daha az yer vermesi, bu becerilerin yükseköğretimde kazandırılabilecek insani beceriler olarak görülmediği şeklinde yorumlanabilir.

\section{İnsani Becerilerin Yükseköğretimde Öğrenenlere Kazandınlması}

İnsani beceriler konusundaki genel düşünce; bu becerilen bireylere kazandırılmasının çok önemli ancak zor olduğudur. Hazzan ve Har-Shai (2013) insani becerilerin öğretilemez ve üzerinde çalışılamaz olduğunu; öğrenenlerin aktif katılım-öğrenme-öğrendiklerini yansıtma stratejileri ile zaman içerisinde kendi kendilerine kazanabileceklerini savunmaktadır. Benzer 
şekilde Aricia (2013) bu becerilerin zaman içerisinde geliştirilebileceğini; Urs-Sorana (2013) ise bazılarının öğretilemez olduğunu iddia etmektedir.

Yükseköğretim uygulamaları incelendiğinde ise pek çok üniversitenin sürekli değişen mesleki/sosyal yaşam şartlarında insani becerilerin bireylerin başarılı olabilmesi için önemli olduğunu kabul ettiği, teknik becerilerin yanı sıra insani becerilerin kazandırılmasını da önemsediği ve bu yönde çalışmalar yaptığı görülmektedir (Chen, 2010; Evenson, 1999; Fullan ve Scott 2014; Gabriel-Petit 2017; Hytti ve O'Gorman 2004; Whiteside et al. 2017; Wiek, Withycombe, ve Redman 2011). Ancak bu çalışmalarda, insani becerilerin kazandırılmasında ortak ve ideal bir modelin olmadığ 1 görülmektedir. İnsani becerilerin kazandırılmasında ilgili eğitim kurumunun, programın, disiplininin özelliklerinin dikkate alınması (Kechagias, 2011) ve farklı stratejilerin geliştirilmesi gerektiği belirtilmektedir (Wilhelm et al., 2002). İnsani becerilerin kazandırılmasında ilk adım; bu becerilerin önemi ve onlar olmadan mezun olunması durumunda karşılaşılacak sorunlara ilişkin öğrenenlere farkındalık kazandırmaktır (Schulz, 2008).

İnsani becerilerin yükseköğretimde öğrenenlere kazandırılmasına ilişkin öneriler ve kullanılabilecek yöntem/teknik/uygulamalar Tablo 2'de özetlenmiştir (Cimatti, 2016; Russell, Russell, ve Tastle , 2005; Schulz, 2008; Taylor, 2016):

Tablo 2: İnsani becerilerin yükseköğretimde öğrenenlere kazandırılmasına ilişkin öneriler ve kullanılabilecek yöntem/teknik/uygulamalar

\begin{tabular}{|c|c|c|}
\hline Öneriler & 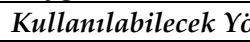 & tem/Teknik/Uygulamalar \\
\hline $\begin{array}{l}\text { Öğrenenlerin aktif öğrenmesi sağlan- } \\
\text { malıdır. }\end{array}$ & $\begin{array}{l}\text { *Tartışma } \\
\text { *Görüşme } \\
\text { *Panel } \\
\text { *Soru-cevap }\end{array}$ & $\begin{array}{l}{ }^{*} \text { Nöro linguistik program- } \\
\text { lama } \\
{ }^{*} \text { Altı şapkalı düşünme } \\
{ }^{*} \text { Sunum }\end{array}$ \\
\hline $\begin{array}{l}\text { Öğrenenlerin işbirliğine dayalı öğren- } \\
\text { mesi sağlanmalıdır. } \\
\text { Farklı fakültelerdeki veya programlar- } \\
\text { daki öğrenenler belirli bir amaç için bir- } \\
\text { likte çalışmalıdır. }\end{array}$ & $\begin{array}{l}\text { *Takım çalışmaları } \\
\text { *Proje } \\
\text { *Gezi } \\
{ }^{*} \text { Çalıştay }\end{array}$ & $\begin{array}{l}\text { *Örnek olay } \\
{ }^{*} \text { Altı şapkalı düşünme } \\
{ }^{*} \text { Ortak seçmeli dersler }\end{array}$ \\
\hline $\begin{array}{l}\text { Öğrenenlerin, iş ve sosyal ortamlarda } \\
\text { kişilerle diyalog kurması sağlanmalı- } \\
\text { dır. }\end{array}$ & $\begin{array}{l}\text { *Görüşme } \\
\text { *Proje } \\
{ }^{*} \text { Gezi }\end{array}$ & $\begin{array}{l}\text { *Çalıştay } \\
\text { *Örnek olay } \\
\text { *Öğrenen kulüplerine } \\
\text { katılma }\end{array}$ \\
\hline
\end{tabular}




\begin{tabular}{|c|c|c|}
\hline $\begin{array}{l}\text { Öğrenenler, iş ortamlarına maruz kal- } \\
\text { malıdır. }\end{array}$ & $\begin{array}{l}\text { *Gönüllü projeler } \\
{ }^{*} \text { Bitirme projeleri }\end{array}$ & $\begin{array}{l}{ }^{*} \text { Staj } \\
{ }^{*} \text { Kisa süreli çalışma olanak- } \\
\text { ları }\end{array}$ \\
\hline $\begin{array}{l}\text { Öğrenenlerin belirlenen kitapları oku- } \\
\text { ması sağlanmalıdır. }\end{array}$ & $\begin{array}{l}\text { *Tartışma } \\
\text { *Sunum } \\
\text { *Panel }\end{array}$ & $\begin{array}{l}\text { *Soru-cevap } \\
\text { *Münazara }\end{array}$ \\
\hline $\begin{array}{l}\text { Öğrenenlere becerilerin neler olduğu } \\
\text { açıklanmalı, farkındalık yaratılmalıdır. }\end{array}$ & $\begin{array}{l}\text { *Sunum } \\
\text { *Panel } \\
\text { *Problem çözme }\end{array}$ & \\
\hline $\begin{array}{l}\text { Öğrenenlerin kazandıkları becerileri } \\
\text { sergilemelerine imkân sağlanmalıdır. }\end{array}$ & $\begin{array}{l}{ }^{*} \text { Görüşme } \\
{ }^{*} \text { Proje } \\
{ }^{*} \text { Gezi } \\
{ }^{*} \text { Çaliştay }\end{array}$ & $\begin{array}{l}\text { *Örnek olay } \\
\text { *Simülasyon } \\
\text { *Rol oynama } \\
\text { *Topluluklara katılma }\end{array}$ \\
\hline
\end{tabular}

Not: Bu tablo alanyazın taraması sonucunda araştırmacılar tarafından hazırlanmıştır.

Ayrıca Alman üniversitelerinde "sosyal kredi toplama sistemi" (Philipose 2010), Avustralya üniversitelerinde "hizmet öğrenmesi" (Evans ve Sawyer 2009), Türk üniversitelerinde ise "topluma hizmet uygulamalar1" adlı farklı uygulamalar, öğrenenlerin insani becerileri kazanmasında etkili olabilir.

\section{Öz Yönelimli Öğrenme Modeli (Self Directed Learning Model) Ve Yük- seköğretimde Uygulanması}

\section{Öz Yönelimli Öğrenme Modeli}

Öz yönelimli öğrenme modeli, bireyin kendi öğrenme sürecini yönetmesidir. İlgili alanyazın incelendiğinde bu modelin bağımsız öğrenme, özplanlı öğrenme, otonom öğrenme, öz-eğitim (Hiemstra, 1996; Roberson, 2005); öz-yönelimli öğrenme, isteklendirme, üst-biliş ve öz-düzenleme (Long, 2000; Murnane ve Levy, 1996; Taylor, 1995); kendi kendine planlayarak öğrenme, kendi kendine öğretme, kendi kendine öğrenme, özerk öğrenme ve bağımsız çalışma, öz-yönetim, öz-izleme ve kendini yeniden düzenleme (Garrison, 1997) gibi çok çeşitli şekillerde adlandırıldığı ve tanımlandığ1 (Knowles, 1975; Tough,1979; Iwasiw,1987; Spencer ve Jordan,1999; Slevin ve Lavery,1991; Fisher, King ve Tague 2001) belirlenmiştir. Slevin ve Lavery (1991) öz yönelimli öğrenme kavramıla ilgili belirle- 
nen bu çeşitliliğin öz yönelimli öğrenmenin bireysel bir model olmasından kaynaklandığını ileri sürmektedir. İngilizce "self directed learning" kavramının karşılığı olarak yerli alanyazında genellikle "öz yönetimli öğrenme" kavramı kullanılmaktadır. Ancak bu araştırmada "öz yönelimli öğrenme" kavramının kullanılması tercih edilmiştir.

Öz yönelimli öğrenme modeline ilişkin tanımlar incelendiğinde her birinde öne çıkan vurgunun farklılaştığı görülmektedir. Örneğin; Tough (1979) (akt. Merriam ve Caffarella, 1999) öz yönelimli öğrenme sürecinde planlama ve karar verme aşamalarının önemini vurgulamakta ve bu modeli “özel aşamaları olan” bir öğrenme süreci şeklinde tanımlamaktadır. Senge (1992) bu modeli, bireyin bilgilerini ve becerilerini kullanarak, deney/gözlem yoluyla elde ettiği değerleri özümseyerek gerçekleştirdiği bireysel öğrenme süreci şeklinde tanımlamıştır. Saks ve Leijen (2014) ise bu modeli seçip uygulayabilme ve öğrenme sonuçlarını değerlendirebilme süreci olarak tanımlamıştır. İlgili tanımların neredeyse tamamında "süreç" kavramına odaklanılmaktadır. Iwasiw (1987) ve Spencer ve Jordan (1999) da benzer şekilde öz yönelimli öğrenmenin bir süreç olduğunu vurgulamıştır. Son olarak, Knowles (1975) da öz yönelimli öğrenmenin kapsamlı bir süreç olduğunu ve birçok adımda gerçekleştiğini belirtmiştir.

Pek çok araştırmacının vurguladığı gibi, öz yönelimli öğrenme, kapsamlı bir süreçtir ve bu sürecin başarıyla tamamlanabilmesi için bazı işlem basamaklarının gerçekleştirilmesi gerekmektedir. Aşağıda alanyazın taraması sonucunda belirlenen öz yönelimli öğrenme sürecinin işlem basamakları gösterilmektedir.

Tablo 3'te görüldüğü gibi, işlem basamaklarının sayısı değişmekle birlikte, öz yönelimli öğrenme süreci farklı araştırmacılar tarafından doğrusal bir akış içerisinde açıklanmaktadır. Ancak bu süreç, öğrenenlerin kendi öğrenme süreç/faaliyetlerini etkin bir şekilde tasarlamasını, uygulamasını, değerlendirmesini ve tekrar harekete geçmesini kapsayan döngüsel bir süreç olmalıdır. Çünkü öz yönelimli öğrenme, yalnızca belirli bir ürünün ortaya çıarılması veya görevin yerine getirilmesiyle son bulan bir öğrenme süreci değil, süreklilik gerektiren döngüsel bir süreçtir. 
Tablo 3. Öz yönelimli öğrenme sürecindeki işlem basamaklan

\begin{tabular}{|c|c|c|c|c|c|c|}
\hline \multicolumn{7}{|c|}{ İşlem Basamakları } \\
\hline Araştırmacılar & 1.Adım & 2. Adım & 3. Adım & 4. Adım & 5. Adım & 6.Adım \\
\hline $\begin{array}{l}\text { Knowles } \\
\text { (1975) }\end{array}$ & $\begin{array}{l}\text { Öğrenme } \\
\text { girişimde } \\
\text { bulunma }\end{array}$ & $\begin{array}{l}\text { Öğrenme } \\
\text { gereksi- } \\
\text { nimlerini } \\
\text { belirleme }\end{array}$ & $\begin{array}{l}\text { Öğrenme } \\
\text { hedeflerini } \\
\text { belirleme }\end{array}$ & $\begin{array}{l}\text { Öğ- } \\
\text { renme } \\
\text { için kay- } \\
\text { nak be- } \\
\text { lirleme }\end{array}$ & $\begin{array}{l}\text { Öğrenme } \\
\text { strateji- } \\
\text { sine karar } \\
\text { verme }\end{array}$ & $\begin{array}{l}\text { Öğrenme } \\
\text { çıktılarını } \\
\text { değerlen- } \\
\text { dirme }\end{array}$ \\
\hline Iwasiw (1987) & $\begin{array}{l}\text { Öğrenme } \mathrm{g} \\
\text { rini belirleme }\end{array}$ & reksinimle- & $\begin{array}{l}\text { Öğrenme } \\
\text { hedeflerini } \\
\text { belirleme }\end{array}$ & $\begin{array}{l}\text { Öğ- } \\
\text { renme } \\
\text { kaynak- } \\
\text { larını be- } \\
\text { lirleme }\end{array}$ & $\begin{array}{l}\text { Öğrenme } \\
\text { stratejile- } \\
\text { rini belir- } \\
\text { leme }\end{array}$ & $\begin{array}{l}\text { Öğrenme } \\
\text { ürünü de- } \\
\text { ğerlen- } \\
\text { dirme }\end{array}$ \\
\hline $\begin{array}{l}\text { Spencer ve } \\
\text { Jordan (1999) }\end{array}$ & $\begin{array}{l}\text { Öğrenme giri } \\
\text { bulunma ve } \\
\text { lerini belirlen }\end{array}$ & $\begin{array}{l}\text { iminde } \\
\text { gereksinim- } \\
\text { e }\end{array}$ & $\begin{array}{l}\text { Hedeflerini } \\
\text { oluşturma }\end{array}$ & $\begin{array}{l}\text { Kaynak- } \\
\text { ları be- } \\
\text { lirleme }\end{array}$ & $\begin{array}{l}\text { Uygun ak- } \\
\text { tiviteleri } \\
\text { seçme }\end{array}$ & $\begin{array}{l}\text { Sonucu } \\
\text { değerlen- } \\
\text { dirme }\end{array}$ \\
\hline $\begin{array}{l}\text { Caffarella } \\
(2000) ; \quad \text { Mer- } \\
\text { riam ve Caffa- } \\
\text { rella (1999) }\end{array}$ & $\begin{array}{l}\text { Öğrenme } \\
\text { sorumlulu- } \\
\text { ğunu alma }\end{array}$ & Öğrenmeye & lişkin planlar & yapma & $\begin{array}{l}\text { Öğren- } \\
\text { meyi ger- } \\
\text { çekleş- } \\
\text { tirme }\end{array}$ & $\begin{array}{l}\text { Değerlen- } \\
\text { dirme } \\
\text { yapma }\end{array}$ \\
\hline $\begin{array}{l}\text { Ambrose, } \\
\text { Bridges, Dipi- } \\
\text { etro, Lovett ve } \\
\text { Norman (2010) }\end{array}$ & Hedef saptam & & $\begin{array}{l}\text { Değerlen- } \\
\text { dirme }\end{array}$ & $\begin{array}{l}\text { Plan- } \\
\text { lama }\end{array}$ & $\begin{array}{l}\text { Uygu- } \\
\text { lama-iz- } \\
\text { leme }\end{array}$ & Yansitma \\
\hline
\end{tabular}

Not: Bu tablo, alanyazın taraması sonucunda araştırmacılar tarafından hazırlanmıştır.

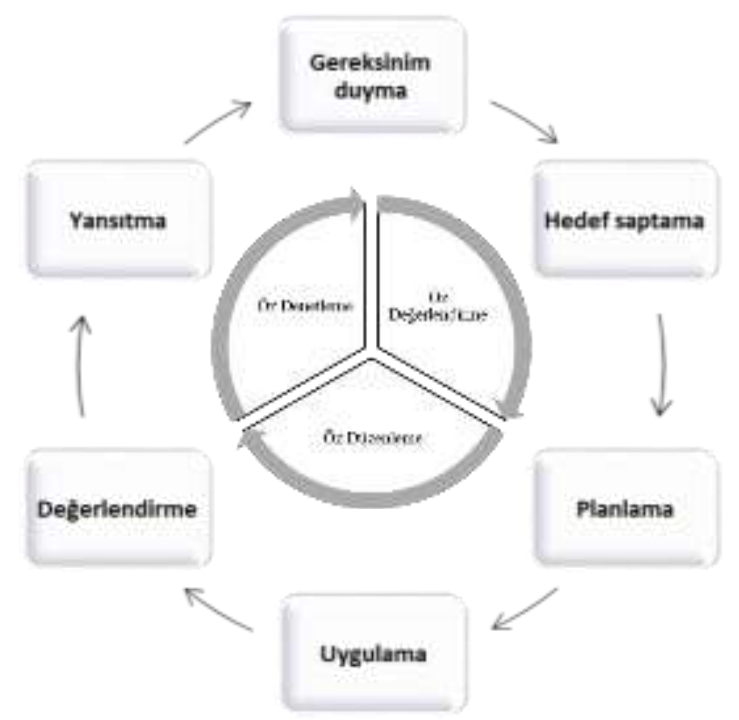


Şekil 1. Öz yönelimli öğrenme sürecinin döngüsel gösterimi ve işlem basamakları. (Araştırmacılar tarafından geliştirilmiştir.)

Şekil 1'de yer alan diyagramdan anlaşıldığ üzere öz yönelimli öğrenme süreci, gereksinim duyma, hedef saptama, planlama, uygulama, değerlendirme, yansıtma basamaklarından oluşmaktadır. Ancak yansıtma basamağından sonra, süreç tekrar başlamalıdır. Öğrenenler her bir basamakta, öz denetleme, öz değerlendirme ve öz düzenleme yaparak bir sonraki basamağa geçmelidir.

Tablo 3 ve Şekil 1'de de görüldüğü gibi öz yönelimli öğrenme sürecinde öğrenenlerin kendi öğrenme süreçlerini etkin bir şekilde tasarlayıp sürdürmeleri beklenmektedir. Yükseköğretimde uygulanması durumunda öğrenenlerin süreci aktif bir şekilde başlatmaları, sürdürmeleri, kendi kendilerini motive etmeleri; öğretim elemanlarının/danışmanların ise süreçte rehber rolü üstlenmesi gerekmektedir.

Öz yönelimli öğrenme modelinde, öğrenenlerin sürece etkin katılımı, onların akademik başarılarını olumlu yönde etkilemektedir (Chou, 2009; Edmondson, Boyer, Artis, Solomon, ve Fleming, 2012; Hsu ve Shiue, 2005; Long, 1991; Suknaisith, 2014). Çünkü öğrenenler öz yönelimli öğrenme sayesinde transfer edilebilir bilişsel ve meta bilişsel beceriler kazanmakta, bu beceriler onların gelecekte de başarılı öğrenme faaliyetleri gerçekleştirmelerine olanak sunmaktadır. Öğrenenlere olumlu tutum geliştirme, akılcı davranma, karar verme, eleştirel düşünme, yaratıcı düşünme, problem çözme, etkili konuşma ve yazma gibi temel beceriler ile özgüven, merak ve keşfetme isteği (Edmondson, Boyer, ve Artis, 2012; Smith, 2002) kazandırmaktadır. Öz yönelimli öğrenme, mesleki başarı için de gerekli ve önemli olan becerilerin kazandırılmasına olanak sağlamaktadır (Artis ve Harris, 2007; Cron, Marshall, Singh, Spiro ve Sujan, 2005; Mayes, 2009; Tobin, 2000). Ayrıca alan yazında öz yönelimli öğrenme seviyeleri yüksek olan bireylerin mesleki başarılarının yüksek olduğu, üretken ve iş değişiminde başarılı oldukları vurgulanmaktadır (Durr, 1992; Guglielmino ve Guglielmino, 1991; Muller, 2007; Roberts, 1986).

\section{Öz-Yönelimli Öğrenme Modelinin Yükseköğretime Uyarlanması ve Uygulanması}


Öz-yönelimli öğrenme, yükseköğretimde uygulanması önerilen bir modeldir (Garrison, 1997). Çünkü yükseköğretim kademesindeki öğrenenler, belirli bir hazırbulunuşluk düzeyine sahiptir ve öz-yönelimli öğrenmenin bunun üzerine yapılandırılması beklenmektedir (Garrison, 1997). Ayrıca öz yönelimli öğrenme, yükseköğretim kademesindeki öğrenenlerin profillerine uygun olacak şekilde mekân ve zamana bağımlı öğrenmeyi ortadan kaldırdığından yükseköğretim için daha uygundur (Garrison, 1997). Ancak Dynan, Cate ve Rhee (2008) tarafından vurgulandığı gibi üniversiteye yeni başlayan öğrenenlerin çoğunluğu öz-yönelimli öğrenmeye hazır değildir ve öz-yönelimli öğrenme hazırbulunuşluk düzeyi farklı programlardaki öğrenenler arasında oldukça farklılık göstermektedir (Yuan, Williams, Fang, ve Pang, 2012). Yerli alan yazında birinci sınıf için olmasa da üç ve/veya dördüncü sinıflar üzerinde yapılan araştırmada da öğrenenlerin öz-yönelimli öğrenme hazırbulunuşluk düzeylerinin farklılaştığı görülmektedir (Aşkın, 2015; Hürsen, 2016; Karataş, 2017; Sarmasoğlu ve Görgülü, 2014).

Yükseköğretimde öz-yönelimli öğrenme modeli uygulanırken projelerden faydalanılabilir. Tough (1967), bu projelerin; önceden planlanmış, en az altı aylık zaman diliminde en az yedi saatlik farklı etkinlikleri kapsaması ve öğrenenlere belirli bilgi/beceriler kazandırması ve kalıcı etkisi olması gerektiğini belirtmiştir. Clardy (2000) ise, öz yönelimli öğrenme modelinde kullanılabilecek projeleri aşamalı şekilde açıklayarak, dört tür belirlemiştir. Edmondson, Boyer ve Fleming (2012), bu projeleri eğitim bağlamı dışından örnekler vererek açıklamıştır. Aşağıda Clardy (2000) tarafından yapılan sonoflandırma temel alınarak yükseköğretimde öz-yönelimli öğrenme modelinin uygulanmasında kullanılabilecek proje türleri açıklanmıştır:

Başlatılmış (Induced) Projeler: Bu tür projeler, bir öğretim elemanı tarafından gerçekleştirilmesi zorunlu tutulan projelerdir. Eğer öğrenenler, herhangi bir konuyla ilgili bilmeleri gereken şeylerin ne olduğunu, bunlara nasıl ulaşacağını veya öğrenme hedeflerini nasıl gerçekleştireceğini bilmiyorlarsa bir başkası tarafından başlatılmış olan bu tür projeler kullanılabilir. Projelerin ne olduğu ve içeriği, öğretim elemanları tarafından belirleniyor olsa bile öğrenenler kendi öğrenme süreçlerini düzenleyerek öz yönelimli öğrenme gerçekleştiriler (Artis ve Harris, 2007). 
Sinerjik (Eş etkin- Synergistic) Projeler: "Geçit fırsatları" olarak da adlandırılan bu projelerde; eğitim materyali üniversite/öğretim elemanı tarafından sunulur, öğrenenler projeye katılma/katılmama tercihi yapar ve öğretim elemanları onların öğrenme durumlarını değerlendirir. Eğer öğrenenler ne tür bilgiye ihtiyaç duyduklarını biliyor; ancak bilgiye nasıl ve nereden ulaşacaklarını bilmiyorlarsa bu tür projeler yararlı olacaktır. Artis ve Harris (2007), kurumsal kütüphaneleri buna örnek olarak göstermektedir. Üniversite kütüphaneleri bu kapsamda değerlendirilebilir: Üniversiteler kütüphaneler aracılığıyla çalışılacak materyalleri, kitapları, elektronik kaynakları öğrenenlere sunmaktadır, ancak öğrenenler ne çalışacaklarına ve öğrendikleri bilgileri nasıl uygulayacaklarına karar vermektedir.

Gönüllï (Voluntary) Projeler: Bu tür projeler, tamamen öğrenenler tarafından gerçekleştirilir. Onlar hangi bilginin gerekli olduğunu, bu bilgilere nasıl ulaşacaklarını ve öğrendiklerini nasıl değerlendireceklerini bildikleri zaman bu projeler uygulanır. Örneğin; bir eğitim fakültesi öğrencisi öğretmen olarak Türkçeyi doğru ve etkili konuşması gerektiğini fark eder ve daha sonra bağımsız olarak istenen yetkinliği elde etmek için gerekli bilgileri arar, bulur, öğrenir.

Öz-yönelimli (Tarama-Scanning) Projeler: Bu tür projeler, öğrenenlerin, hangi bilginin gerekli olduğunu, gerekli bilgileri nerede bulacağını, nasıl gruplandıracağını, kullanacağını ve öğrendiklerini nasıl değerlendireceklerini belirlemeleri açısından gönüllü projelere benzemektedir. Ancak özyönelimli projeler, önceden belirlenmiş bir sonu olmayan projelerdir. Örneğin; bir eğitim fakültesi öğrencisi, öğretmen olarak güncel bilgileri/bilimsel gelişmeleri sürekli takip etmesi gerektiğinin farkına varır ve daha sonra bağımsız olarak istenen yetkinliği elde etmek için gerekli bilgileri arar, bulur, öğrenir ve bu işlemi sürekli tekrar eder.

Öz-yönelimli öğrenme modelinin uygulanmasına ilişkin Grow (1991), dört aşamalı bir öğrenme sürecini açılamaktadır. Bu süreç, yükseköğretime de uyarlanabilir. Ancak bu aşamalı sürecin yükseköğretimde nasıl uygulanacağı, hangi aşamadan başlanacağı veya hangi aşamaların tamamlanmasının amaçlandığı; öğrenenlerin hazırbulunuşluk düzeylerine, onlara kazandırılmak istenen niteliklere ve öğretim elemanlarının eğitim 
vizyonuna göre değişiklik gösterebilir. Tablo $4^{\prime}$ te öz yönelimli öğrenme modelinin yükseköğretimde uygulanması Grow (1991) tarafından yapılan uygulama önerileri, Clardy'un (2000) açıkladığı proje türleri ile ilişkilendirilerek açıklanmıştır:

Tablo 4. Öz-yönelimli Ö̆̆grenme Modelinin Yükseköğretimde Uygulanması

\begin{tabular}{|c|c|c|c|c|}
\hline & $\begin{array}{l}\text { Öğrenenin } \\
\text { Rolü }\end{array}$ & $\begin{array}{l}\text { Öğretenin } \\
\text { Rolü }\end{array}$ & Açıklamalar & Uygun Projeler \\
\hline 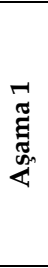 & $\begin{array}{l}\text { Bağımlı } \\
\text { (Depen- } \\
\text { dent) }\end{array}$ & $\begin{array}{l}\text { Otorite, } \\
\text { Koç }\end{array}$ & $\begin{array}{l}\text { Öğrenenler, öğretim elemanları tara- } \\
\text { fından kendilerine verilen görevleri } \\
\text { yapar. Projenin konusu, yapılışı, nasıl } \\
\text { değerlendirileceği öğretim elemanı ta- } \\
\text { rafından belirlenir. Öğretim elemanı; } \\
\text { süreçte onlara dönütler vererek koçluk } \\
\text { yapar. }\end{array}$ & $\begin{array}{l}\text { Başlatılmış } \\
\text { Projeler }\end{array}$ \\
\hline 尔 & $\begin{array}{l}\text { İlgili } \\
\text { (Interest) }\end{array}$ & $\begin{array}{l}\text { Güdüle- } \\
\text { yen, } \\
\text { Rehber }\end{array}$ & $\begin{array}{l}\text { Öğretim elemanının, öğrenenleri gü- } \\
\text { düleme rolü ön plandadır. Bunun için } \\
\text { ilham verici dersler ve rehberlik çalış- } \\
\text { maları yaparak öğrenenlerin daha } \\
\text { fazla ilgili olması sağlanır. Ayrıca öğ- } \\
\text { renenlere hedef belirleme ve öğrenme } \\
\text { stratejileri konularında rehberlik yapı- } \\
\text { lır. }\end{array}$ & $\begin{array}{l}\text { Sinerjik } \\
\text { Projeler }\end{array}$ \\
\hline 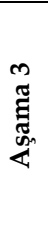 & $\begin{array}{l}\text { Dahil } \\
\text { Olmuş } \\
\text { (Involved) }\end{array}$ & $\begin{array}{l}\text { Kolaylaşt1- } \\
\text { rıc1 }\end{array}$ & $\begin{array}{l}\text { Öğrenenler, kendi öğrenme sürecine } \\
\text { daha fazla dâhil olur. Öğretim elemanı } \\
\text { ise düzenlediği tartışma, seminer, } \\
\text { grup çalışmalarında bir katılımcı ola- } \\
\text { rak rol alır ve süreci kolaylaştırmaktan } \\
\text { sorumludur. }\end{array}$ & $\begin{array}{l}\text { Gönüllü } \\
\text { Projeler }\end{array}$ \\
\hline 范 & $\begin{array}{l}\text { Öz } \\
\text { Yönelimli } \\
\text { (Self } \\
\text { Directed) }\end{array}$ & $\begin{array}{l}\text { Danışman, } \\
\text { Yetki } \\
\text { veren kişi }\end{array}$ & $\begin{array}{l}\text { Öğrenenler, kendi öğrenme sürecinin } \\
\text { yönetim ve denetiminden sorumlu- } \\
\text { dur. Öğretim elemanı ise öğrenenleri } \\
\text { yetkilendiren ve gereksinim duyduk- } \\
\text { larında onlara yardımcı olan kişidir. } \\
\text { Öğrenenler; staj yaparken, tez yazar- } \\
\text { ken ya da diğer bireysel çalışmaları } \\
\text { gerçekleştirirken bu aşamaya ulaşmış } \\
\text { olurlar. }\end{array}$ & $\begin{array}{l}\text { Öz Yönelimli } \\
\text { Projeler }\end{array}$ \\
\hline
\end{tabular}

Not: Tablo, Grow (1991:130) ve Clardy'un (2000) görüşleri temel alınarak araştırmacılar tarafindan hazırlanmıştır.

Öz-yönelimli öğrenme modelinin etkili bir şekilde uygulanabilmesi için aşağıdaki ilkeler göz önünde bulundurulmalıdır (Grow, 1991; Nasri, 2017): 
- Öğrenenlerin öz yönelimli çalışabilme düzeyine göre öğretim faaliyetleri, öğrenme etkinlikleri, güdüleme stratejileri belirlenmelidir.

- Öğrenme ve öğretme kaynakları çeşitlendirilmelidir.

- Akran öğrenme uygulamaları artırılmalıdır.

- Öğretim elemanı-öğrenenler arasında olumlu ve işbirliğine dayalı bir ilişki kurulmalıdır.

- Öğretim elemanları, öz yönelimli öğrenme için engel teşkil edebilecek sınırlamaları ve öz yönelimli öğrenme sürecini kolaylaştıracak kaynakların farkında olmalıdır.

- Üniversiteler, öğretim elemanlarını; hizmet içi eğitimler düzenleyerek, onları teşvik ederek, destekleyerek öz yönelimli öğrenme uygulamaları yapmaları konusunda onlara yardımcı olmalıdır.

Öz-yönelimli öğrenme modelinin yükseköğretimde uygulanmasına ilişkin ilkeler, öneriler ve kullanılabilecek yöntem/teknik/uygulamalar dikkate alındığında, bu modelde öğrenmenin değerlendirilmesinde standart veya genel sınavların faydalı olmayacağı görülmektedir. Alanyazında, öz-yönelimli öğrenmenin değerlendirilmesinde etkili yöntemlerden biri olarak ürün dosyaları (portfolyo) gösterilmektedir (Kicken, Brand-Gruwel, ve Van Merrienboer, 2008). Çünkü ürün dosyaları, anlamlı öğrenme gerçekleşmesine ve öğrenenlerin kendi öğrenme sürecini izlemelerine olanak sağlamaktadır.

\section{Öz Yönelimli Öğrenme Modelinin Yükseköğretimde Öğrenenlere İnsani Becerilerin Kazandırılmasında Etkililiği}

Yükseköğretime devam eden öğrenenler, yetişkinlerdir ve öz-yönelimli öğrenme modeli yetişkin eğitimi ilkelerine uygun şekilde yükseköğretimde kullanılabilecek etkili modeller arasındadır. Yetişkinlerin nasıl ve niçin öğrendikleri konusundaki çalışmaların öncüsü olan Houle (1961), yetişkinler öğrenenleri bilgi edinme odaklı öğrenme faaliyeti gerçekleştirenler olarak tanımlamıştır. Houle'un (1961) görüşlerini temel alan Knowles'ın (1984) geliştirdiği yetişkin eğitimi kuramı dört maddede özetlenebilir:

- Yetişkinler, kendi öğrenme faaliyetlerini planlama ve değerlendirme süreçlerine katılmalıdır.

- Deneyimler (hatalar da dahil) öğrenmenin temelini oluşturmalıdır. 
- Yetişkinler, kendi kişisel veya mesleki yaşamları için önemli olan konulara karşı çok daha ilgilidir.

- Yetişkinlerin öğrenmesi, içerikten çok sorun merkezli olmalıdır.

Knowles'in (1984) kuramı göz önünde bulundurularak, öz yönelimli öğrenme modelinin yetişkin eğitimine uygun olduğu iddia edilebilir. Çünkü bu modelde öğrenenler, kendileri için önemli olan konuyu (Madde 3) ve sorunları (Madde 4) temel alarak, kendi öğrenme süreçlerini düzenlemekte ve kontrol etmekte (Madde 1), yaptıkları ara değerlendirme ve yansitmalar aracılığıyla ön öğrenmelerinden faydalanarak öğrenme süreçlerini tamamlamaktadır.

Merriam (2001), öz yönelimli öğrenme modelinin yetişkin eğitimine uygunluğunu anlatmak için üç önemli kavramı açıklamaktadır:

Hümanizm: Kişisel gelişim isteği, yetişkin eğitiminin temel amacıdır (Merriam ve Caffarella, 1999). Yetişkinlerin, yaşam tecrübeleri, ön öğrenmeleri ve motivasyonları öz yönelimli öğrenme modelinin etkili bir şekilde uygulanmasına olanak sağlamaktadır.

Dönüşümsel öğrenme: Dönüşümsel öğrenme, yetişkinlerin kendi deneyimlerinden nasıl anlamlar çıkardığı ve bunun onların öğrenmesini nasıl etkilediği ile ilgilidir. Merriam ve Caffarella'a (1999) göre öz yönelimli öğrenmenin merkezinde dönüşümsel öğrenme yer almaktadır.

Özgürlükçü öğrenme: Merriam'a (2001, s.9) göre yetişkinler, birey olmaktan öte daha sosyal ve politik varlıklardır. Öz yönelimli öğrenme, öğrenenlerin hem birey hem de kolektif olarak hareket etmelerinde etkilidir.

Merriam'ın (2001) bu açıklamaları Brookfield (2013) tarafından şöyle özetlenmiştir:

“Öz yönelimli öğrenme, güç ve kontrole ilişkin bir kavramdır. Öz yönelimli öğrenme sürecinde neyin öğrenilmesi gerektiğine, bilgiyi/eğitim programını kimin düzenleyeceğine karar verme gücü kimindir? Bunların gerçekleşip gerçekleşmediğini kim kontrol eder? Öz yönelimli öğrenme sürecinde öğrenenlerin kendi yaşamları üzerinde kontrolü daha da fazlalaşmakta, bu da özgürlükçü öğrenmeyle ilişkilendirilmektedir" (Brookfield, 2013, s.95).

Bütün bu açılamalar öz-yönelimli öğrenme modelinin yükseköğretim kademesinde bulunan ve yetişkin öğrenenler olarak kabul edilen üniversite öğrencileri için uygun olduğunu göstermektedir. Alanyazında da sıklıkla vurgulandığı üzere, öz yönelimli öğrenme, üniversite öğrencilerinin 
öğrenmelerinde etkili olabilecek önemli modellerden biri olabilir (Brookfield, 2013; Candy, 1991: Xiii, Ellinger, 2004; Merriam ve Caffarella, 1999; Percival, 1996; Saks ve Leijen, 2014). Başka bir ifade ile öz-yönelimli öğrenme, yükseköğretime devam eden öğrencilerin -yetişkinlerin- insani beceriler kazanmasında etkili modellerden biridir. Çünkü öz-yönelimli öğrenme, üniversite öğrencilerinin pek çok beceri, tutum ve değer kazanmasını sağlamaktadır (Brockett ve Hiemstra, 1991; Candy, 1991; Chou, 2009; Guglielmino ve Guglielmino, 1991; Merriam ve Caffarella, 1991; Gibbons, 2002). Bu beceri, tutum ve değerler incelendiğinde, büyük çoğunluğunun alan yazında insani beceriler olarak sıralanan nitelikler arasında yer aldığı görülmektedir.

Tablo 5 incelendiğinde, öz yönelimli öğrenme modeli kullanılarak kazandırılan nitelikler ile alanyazında üzerinde uzlaşılan insani becerilerin büyük oranda örtüştü̆̆̈̈ görülmektedir. Bu nedenle, öz-yönelimli öğrenme uygulaması ile insani becerilerin kazanılabileceği düşünülebilir. Ancak öz yönelimli öğrenme modeli ile kazandırılan bilişsel beceriler, yaşam boyu öğrenme, metabilişsel beceriler, transfer etme gibi bazı niteliklerin kapsamı oldukça geniştir. Bu nedenle bu niteliklerin insani beceriler boyutunda vurgulanmadığı düşünülebilir. Ayrıca bu nitelikleri kazanan bireylerin insani becerileri kazanma olasılığının da artacağı düşünülebilir. Öte yandan, kültürler arası ilişkiler ve takım çalışması gibi becerilerin de daha önce açıklanan kişilerarası beceriler grubunda olduğu için daha çok kişisel becerilere odaklanılan öz yönelimli öğrenme modeli ile kazandırılan nitelikler arasında vurgulanmaması olasıdır. Özet olarak, öz-yönelimli öğrenme modeli ile kazandırılan nitelikler ile insani beceriler birbiri ile yakından ilişkilidir. Farklılaşan nitelik/becerilerin ise öz yönelimli öğrenme sürecinde yapılacak yönlendirmelerle öğrenenlere kazandırılması sağlanabilir. 
Tablo 5. Öz-yönelimli Öğrenme ile Öğrenenlere Kazandırılan Nitelikler ve İnsani Becerilerin Karşılaştırılması

\begin{tabular}{|c|c|}
\hline Öz yönelimli öğrenme ile kazandırılan nitelikler & İnsani beceriler \\
\hline Karar verme & Karar verme \\
\hline Eleştirel düşünme & Eleştirel düşünme \\
\hline Problem çözme & Problem çözme \\
\hline Etkili konuşma ve yazma & $\begin{array}{l}\text { İletişim } \\
\text { Yabancı dil }\end{array}$ \\
\hline Özgüven & Özgüven \\
\hline $\begin{array}{l}\text { Merak } \\
\text { Keşfetme }\end{array}$ & Öğrenme isteği \\
\hline $\begin{array}{l}\text { Olumlu tutum geliştirme } \\
\text { Yaşam doyumu }\end{array}$ & Olumlu tutum \\
\hline Mesleki başarı & $\begin{array}{l}\text { Çalışma etiği } \\
\text { Profesyonellik } \\
\text { Zaman yönetimi } \\
\text { Liderlik } \\
\text { Müşteri yönetimi } \\
\text { Baskıla mücadele } \\
\text { Girişimcilik } \\
\text { Kişilerarası ilişkiler } \\
\text { Kriz yönetimi } \\
\text { Özyönetim }\end{array}$ \\
\hline $\begin{array}{l}\text { Yaşam boyu öğrenme } \\
\text { Metabilişsel beceriler } \\
\text { Yaratıcılık } \\
\text { Bilişsel beceriler } \\
\text { Akılcı davranma } \\
\text { Transfer etme becerisi }\end{array}$ & - \\
\hline- & $\begin{array}{l}\text { Kültürler arası ilişkiler } \\
\text { Takım çalışması } \\
\text { Disiplinlerarası düşünme } \\
\text { Esneklik/belirsizlikle mücadele } \\
\text { Sorumluluk/güvenirlik }\end{array}$ \\
\hline
\end{tabular}

Not: Araştırmacılar tarafindan hazırlanmıştır.

\section{Sonuç ve Öneriler}

Bilgi toplumlarında, öğrenme faaliyetlerinin okul ile sınırlı kalmaması ve öğrenme-öğretme yollarının çeşitlendirilmesi temel amaçlar arasından yer almalıdır. Bu temel amaçların gerçekleştirmede, öz-yönelimli öğrenme gerekli ideallerdendir. 
Öz-yönelimli öğrenme, bireylerin kendi öğrenmeleri konusunda karar vermeleri, planlamaları, uygulamalarına ve değerlendirerek kendi öğrenme tecrübelerini yansıtmalarına imkân sağlamaktadır. Günümüz eğitim kurumlarının öğrenenleri, henüz mevcut olmayan mesleklere hazırlamaya çalıştığı, bilginin her an eskidiği ve yeni bilgiler üretildiği düşünüldüğünde öz-yönelimli öğrenmenin önemi daha iyi anlaşılabilir. Öğrenenlerin geleceğe hazırlanmasına yardımcı olmanın en etkili yollarından biri, kendi öğrenme süreçlerine yön vermeleri konusunda onlara rehberlik etmektir. Çünkü gelecekte öğrenme yaşantılarının yüzde doksanından fazlasının resmi eğitim ortamlarının dışında gerçekleşmesi beklenmektedir (Jennings, 2010). Bu doğrultuda yükseköğretimin bireylerin öğrenmesini sağlama görevi (European Commission, 2014), bireylerin öz yönelimli bir şekilde öğrenmesine olanak sağlama şeklinde değişim gösterebilir.

Öte yandan giderek daha karmaşık ve belirsiz hale gelen dünyada (Whiteside vd., 2017), yükseköğretimin yerleşik hale gelmiş akademik/teknik mükemmeliyet arayışının önemi azalırken insani beceriler konusu çok daha fazla vurgulanmıştır (Urs-Sorana, 2013). Her ne kadar adlandırma, tanımlama, kapsama dahil edilen beceriler açısından farklılaşsa birle insani becerilerin ortak özelliği öğrenenlerin öğrenme sürecine katılımını, kişisel ve mesleki gelişimini sağlamasıdır (Gibb, 2014). Bu nedenle insani becerilere sahip olmanın önemi her geçen gün artmakta ve nasıl kazandırılacağına ilişkin çalışmalara gereksinim duyulmaktadır.

$\mathrm{Bu}$ araştırmada; günümüzde temel gereklilik olarak kabul edilen insani beceriler ve öz yönelimli öğrenme modelinin temel özellikleri incelenmiş, bu modelin yükseköğretimde kullanılmasının uygunluğu ve insani becerilerin kazandırılmasında etkililiği tartışılmıştır. Araştırmada genel olarak; öz yönelimli öğrenmenin, yükseköğretime devam eden öğrencilerin -yetişkinlerin- insani becerileri kazanmasında etkili bir model olduğu sonucuna ulaşılmıştır.

Araştırma sonuçları temel alınarak, insani becerilerin öğrenenlere kazandırılmasının yükseköğretimde uygulanan programların hedefleri arasına dâhil edilmesi önerilebilir. Ayrıca yükseköğretimde lisans/lisansüstü düzeylerdeki araştırma, uygulama odaklı derslerde öz yönelimli öğrenme modelinden ve bu araştırmada geliştirilen döngüsel öz yönelimli öğrenme modelinden faydalanılabilir. Araştırmadan elde edilen bir diğer sonuca 
göre insani beceriler, bu becerilerin kazandırılması ve öz yönelimli öğrenme modelinin yükseköğretimde uygulanmasına yönelik çalışmalar oldukça sınırlıdır. Bu araştırmada, söz konusu kavramların analizi yapılarak aralarındaki ilişki ortaya konulmuştur. Ancak öz yönelimli öğrenme modelinin, yükseköğretimde insani becerileri kazandırılmasında etkili olma durumunu belirlemeye yönelik deneysel veya eylem araştırmaları yapılabilir. Böylece hipotetik nitelikteki bu kavramsallaştırma ve varsayımlar saha çalışmaları ile desteklenmiş olacaktır. 


\title{
EXTENDED ABSTRACT
}

\section{Self-Directed Learning Model to Obtain Learners Soft Skills at Higher Education}

\author{
Hüseyin Şimşek - Elif İlhan \\ Kırşehir Ahi Evran University- Ankara Hacı Bayram Veli University
}

Higher education institutions are expected to train qualified individuals in all areas of life - academic, social and professional. One of the main ways to meet this expectation is to provide effective learning-teaching activities through innovative curricula (Salmi, 2009, p.71). When the related literature is examined, it is found out that the qualifications of trained individuals are called in different ways, namely 21st century skills, lifelong learning skills, life skills, innovation skills and soft skills (Johnston \& McGregor, 2004; Kechagias, 2011). In Turkish literature, "soft skills" term has firstly used by IIlhan, Kalaycı and Demir (2018). The definitions of the term has varied a lot (Taylor, 2016), but a great consensus has been reached on the importance of the skills and the necessity of learners' acquirement at higher education (Bancino and Zevalkink, 2007; Gibb, 2014; Grisi, 2014; Kechagias, 2011; Klaus, 2010; Robles, 2012). On the other hand, the literature analysis shows that the researches on how to acquire soft skills are limited and the opinions on this subject are different from each other (Adomssent et al., 2007; Taylor, 2016). These limitations and differences of views in the literature increase the importance of discussions about what models and methods might be effective in acquiring soft skills at higher education.

This study aims to determine soft skills expected to be acquired by learners at higher education and to discuss the effectiveness of the selfdirected learning model in acquirement of soft skills. For this purpose, the study has been structured under three main headings:

1. Soft skills and their acquirement by learners at higher education

2. Self-directed learning model and its application at higher education

3. Effectiveness of the self-directed learning model in attainment of soft skills 
The study is a traditional review study. Within the scope of the study, basic features of soft skills and the way they are obtained by learners at higher education are discussed. It is also argued about self-directed learning model and its suitability/ effectiveness in gaining soft skills. Lastly, a curricular self-directed learning model that can be applied in obtaining soft skills has been developed. In the data collection and analyse process, the steps offered by Pautasso (2013) have been followed.

Soft skills and their acquirement by learners at higher education: Soft skills are non-technical skills, personal characteristics (Hewitt, 2006; Wilhelm, Logan, Smith, and Szul, 2002) and interpersonal skills (Kechagias, 2011). These skills are not specific to a particular discipline or profession (Yan, Yinghong, Lui, Whiteside and Tsey, 2018). As the findings of the study shows the most repeated soft skills in the literature are; communication, teamwork, problem solving, responsibility / reliability, work ethics, professionalism, flexibility / uncertainty, interpersonal relations, leadership and crisis management. General view about soft skills is that they are very important but difficult to be obtained by learners. There are different methods / techniques / practices that can be used for helping learners the acquirement of soft skills at higher education (Cimatti, 2016; Russell, Russell, \& Tastle, 2005; Schulz, 2008; Taylor, 2016).

Self-directed learning model and its application at higher education: Self-directed learning model is an individual learning process in which learners apply experiment/observation methods and get the knowledge, skills and values (Senge, 1992). As many researchers have emphasized, self-directed learning is a comprehensive process including certain steps. The cyclical self-directed learning model proposed in this study also includes some steps; needs, goal setting, planning, implementation, evaluation, reflection. However, the proposed model here differs from the others because after the reflection step, the process must start again. Learners should proceed to the next level by doing self-regulation, self-evaluation and selfregulation at each level. Self-directed learning is a model proposed for higher education (Garrison, 1997). Because learners at higher education have a certain level of readiness, and self-directed learning is expected to be built upon it (Garrison, 1997). Projects can be utilized when applying the self-directed learning model at higher education. In addition, different 
methods, techniques and applications have been proposed in the literature for the effective implementation of the self-directed learning model (Grow, 1991; Nasri, 2017).

Effectiveness of the self-directed learning model in acquirement of soft skills: The learners attending higher education are adults and the self-directed learning model is one of the effective models that can be used at higher education in agreement with the principles of adult education. Self-directed learning model is one of the effective models in the acquisition of soft skills for the learners at higher education - adults. Because self-directed learning enables university students to gain many skills, attitudes and values (Brockett and Hiemstra, 1991; Candy, 1991; Chou, 2009; Guglielmino and Guglielmino, 1991; Merriam and Caffarella, 1991; Gibbons, 2002). When these skills, attitudes and values are examined, it is seen that most of them are among the qualifications listed as soft skills in the literature.

Based on the explanations/discussions above, at the end of the study, it is concluded that self-directed learning is an effective model for helping the students attending higher education - acquire the soft skills. Based on the results of the study, it may be suggested that the acquisition of soft skills by learners should be included in the objectives of the curricula implemented at higher education. In addition, it was determined in the study that the studies on soft skills, the acquirement of these skills and the application of self-directed learning model at higher education are quite limited. In this study, the relationship between these concepts has been revealed by analyzing them. However, experimental or action studies can be conducted to determine the effectiveness of the self-directed learning model in acquiring soft skills at higher education.

\section{Kaynakça / References}

Adomssent, M., Godemann, J., Michelsen, G., Barth, M., Godemann, J., Rieckmann, M., and Stoltenberg, U. (2007). Developing key competencies for sustainable development in higher education. International Journal of Sustainability in Higher Education, 8(4), 416-430. 
Ambrose, S., Bridges, M., DiPietro, M., Lovett, M., and Norman, M. (2010). How learning works: Seven research-based principles for smart teaching. San Francisco: Jossey-bass.

Andrews, J., and Higson, H. (2008). Graduate employability, 'soft skills' versus 'hard' business knowledge: A European study. Higher Education in Europe, 33(4), 411-422.

Aricia E. L. (2013). Helping students cultivate soft skills. 15 Ocak 2018 tarihinde www.aricialafrance.com adresinden erişildi

Arsalı, Z. (2009). The impact of self-regulation instruction on mathematics achievements and attitudes of elementary school students. International Journal of Environmental ve Science Education, 5(1), 85-103.

Artis, A. B., and Harris, E. G. (2007). Self-directed learning and sales force performance: An integrated framework. Journal of Personal Selling and Sales Management, 27(1), 9- 24.

Arum, R., and Roksa, J. (2011). Academically adrift: Limited learning on college campuses. Chicago: University of Chicago.

Aşkın, İ. (2015). Üniversite öğrencilerinin öz-yönetimli öğrenme becerilerininincelenmesi. Yayınlanmamış Doktora Tezi. Hacettepe Üniversitesi Eğitim Bilimleri Enstitüsü, Ankara.

Azim, S., Gale, A., Lawlor-Wright, T., Kirkham, R., Khan, A., and Alam, M. (2010).The importance of soft skills in complex projects. International Journal of Managing Projects in Business, 3(3), 387-401.

Bancino, R., and Zevalkink, C. (2007). Soft skills: The new curriculum for hardcore technical professionals. Techniques: Connecting Education and Careers, 82(5), 20-22.

Boyer, S. L., Artis, A. B., Solomon, P., and Fleming, D. E. (2012). Improving sales performance with self-directed learning. Marketing Management Journal, 22(22), 61-75.

Brockett, R. G. and Hiemstra, R. (1991). Self-direction in adult learning perspectives on theory, research, and practice. London: Routledge.

Brookfield, S. D. (2013). Powerful techniques for teaching adults. San Francisco, CA: John Wiley.

Caffarella, R. S. (2000). Goals of self-learning. G. A. Straka (Ed.), Conceptions of theoretical self-directed learning: Conceptual considerations (pp. 37-48) içinde. 15 Mart 2018 http://vivo.cornell.edu/display/AIICIPR0203DF692AB00000934] adresinden erişildi. 
Canca, D. (2005). Cinsiyete göre üniversite öğrencilerinin kullandıkları bilişsel ve biliş üstü öz düzenleme stratejileri ile akademik başarıları arasındaki iliş̧inin incelenmesi. Yayınlanmamış yüksek lisans tezi, Yıldız Teknik Üniversitesi, İstanbul.

Candy, P.C. (1991). Self-direction for lifelong learning: A comprehensive guide to theory and practice. Francisco: Jossey-Bass.

Casner-Lotto, J., and Barrington, L. (2006). Are they really ready to work? Employers' perspectives on the basic knowledge and applied skills of new entrants to the 21st century workforce. New York: The Conference Board.

CEDA. [Committee for Economic Development of Australia]. (June, 2015) Australia's future workforce? Melbourne, Australia.

ChangeWorks, Inc. (2006). Professional skills for the office of the future. 20 Nisan 2018 http://www.changeworks1.com/pdf/50.\%20Professional\%20Skills\%20for\%the\%20Office\%20of\%20the\%20Fture.pdf adresinden erişildi.

Chen, Y. (2010). Study on modes of cultivation of innovative entrepreneurship talents. Asian Social Science, 6(12), 57-61.

Chou, P. (2009). The effect of varied concept maps and self-directed learning ability on students' hypermedia learning. Yayınlanmamış Yüksek Lisans Tezi, The Pennsylvania State University, Pennsylvania.

Cimatti, B. (2016). Definition, role for the quality of development, assessment of soft skills and their organizations and enterprises. International Journal for Quality Research, 10(1), 97-130.

Cinque, M. (November, 2015). Comparative analysis on the state of the art of soft skill identification and training in Europe and some Third Countries. Speech at "Soft skills and their role in employability-New perspectives in teaching, assessment and certification" workshop in Bertinoro, FC, Italy.

Clardy, A. (2000). Learning on their own: Vocationally oriented self-directed learning projects. Human Development Quarterly, 11(2), 105-125.

Conference Board, Corporate Voices for Working Families, Partnership for $21^{\text {st }}$ Century Skills, Society for Human Resource Management. (2006). Are they really ready to work? Employers' perspectives on the basic knowledge and applied skills of new entrants to the 21st century workforce. 18 Ocak 2018 www.21stcenturyskills.org/documents/FINAL REPORT PDF9-29-06.pdf adresinden erişildi. 
Creswell, J. W. and Miller, D. L. (2000). Determining validity in qualitative inquiry. Theory into practice, 39(3), 124-130.

Cron, W. L., Marshall, G. W., Singh, J., Spiro, R. L., and Sujan, H. (2005). Salesperson selection, training, and development: Trends, implications, and research opportunities. Journal of Personal Selling and Sales Management, 25(2), 123-136.

Demircan, Y. (2014). 5. sinıf öğrencilerinin sınıf içi etkinlik ve akademik başarı düzeylerine göre öz düzenleme stratejileri ve motivasyonel inançlarının incelenmesi. Yayınlanmamış yüksek lisans tezi, Mersin Üniversitesi, Mer$\sin$.

Dubrin, A. (2004). Leadership: Researching findings, practice, and skills (4th ed.). Boston, MA: Houghton Mifflin.

Durr, R. R. (1992). An examination of readiness for self-directed learning and selected personnel variables at a large Midwestern electronics development and manufacturing corporation. Unpublished doctoral dissertation, Florida Atlantic University, Florida.

Dynan, L., Cate, T., and Rhee, K. (2008). The impact of learning structure on students' readiness for self-directed learning. Journal of Education for Business, 84(2), 96-100.

Edmondson, D. R., Boyer, S. L., and Artis, A. B. (2012). Self-directed learning: A meta- analyticreview of adult learning constructs. International Journal of Education Research, 7(1), 40-48.

Eker, C. (2014). Öz-düzenlemeli öğrenme modellerine karşılaştırmalı bir bakış. Turkish Studies - International Periodical For The Languages, Literature and History of Turkish or Turkic, 9(8), 417-433.

Ellinger, A. D. (2004). Self-directed learning and implications for human resource development. Advances in Developing Human Resources, 6(2), 158-177.

European Commission. (2014). High level group on the modernisation of higher education: New modes of learning and teaching in higher education. Luxembourg: EU.

Evans, N. and Sawyer, J. (2009). Internet Usage in Small Businesses in Regional South Australia: Service Learning Opportunities for a Local University. Education in Rural Australia,19(1), 15-33.

Evenson, R. (1999). Soft skills, hard sell techniques. Making Education ve Career Connections, 74(3), 29-31. 
Fisher, M., King, J. and Tague, G. (2001). Development of a self-directed learning readiness scale for nursing education. Nurse Education Today, 21, 516-525.

Fullan, M. and Geof, S. (2014). New pedagogies for deep learning Whitepaper: Education plus. Seattle, WA: Collaborative Impact SPC.

Gabriel-Petit, P. (2017). 13 human qualities you must have to succeed in work and life. 15 Nisan $2018 \quad$ https://www.uxmatters.com/mt/archives/2014/09/13-human-qualities-you-must-have-to-succeed-inwork-and-life.php adresinden erişildi.

Garrison, D. R. (1997). Self-directed learning: Toward a comprehensive model. Adult Education Quarterly, 48(1), 18-33.

Gewertz, C. (2007). Soft skills in big demand. Education Week, 26(40), 25-27.

Gibb, S. (2014). Soft skills assessment: Theory development and the research agenda. International Journal of Lifelong Education, 33(4), 455-471.

Gibbons, M. (2002). The self-directed learning handbook: Challenging adolescent students to excel. San Francisco, CA Jossey-Bass.

González-Morales, D., De Antonio, L. M. M., and García, J. L. R. (2011). Teaching "Soft" skills in software engineering. Paper presented at the Global Engineering Education Conference (EDUCON), 2011 IEEE.

Greenhalgh, T., Thorne, S., and Malterud, K. (2018). Time to challenge the spurious hierarchy of systematicover narrative reviews? European Journal of Clinical Investigation, 48(6), 12-31.

Grisi, C.G.A. (Kasım, 2014). Soft Skills: A close link between enterprise and ethics. Speech at "Soft Skills and their role in employability - New perspectives in teaching, assessment and certification", workshop in Bertinoro, FC, Italy.

Grow, G. O. (1996). Teaching learners to be self-directed. Adult Education Quarterly, 41(3),125-149.

Guglielmino, L. M., and Guglielmino, P. J. (1991). Expanding your readiness for self-directed learning. Don Mills, Ontario: Organization Design and Development Inc.

Gülpınar, Ö., ve Güçlü, A. G. (2013). Derleme makalesi nasıl yazılır? Turkish Journal of Urology, 39(1), 44-48.

Hart, C. (2018). Doing a literature review: Releasing the research imagination. Los Angels: Sage. 
Harvey, L., Geall, V., and Moon, S. (1997). Graduates' work: Implications of organizational change for the development of student attributes. Industry and Higher Education, 11(5), 287-296.

Hazzan, O. and Har-Shai, G. (2013). Teaching computer science soft skills as soft concepts. In Proceedings of the 2013 Special Interest Group On Computer Science Education Technical symposium.

Hewitt, S. (2006). 9 Soft skills for success. 15 Mart 2018 http://www.askmen.com/money/career 100/121 career.html adresinden erişildi.

Hiemstra, R. (1996). What's in a word? Changes in self-directed learning language over a decade. 22 Mart 2018 http://www-distance.syr.edu/sdlrhl.html adresinden erişildi.

Houle, C. O. (1961). The inquiring mind. Madison WI: University of Wisconsin.

Hsu, Y. C. and Shiue, Y. M. (2005). The effect of self-directed learning readiness on achievement comparing face-to-face and two-way distance learning instruction. International Journal of Instructional Media, 32(2), $143-157$.

Hürsen, C. (2016). The impact of curriculum developed in line with authentic learning on the teacher candidates' success, attitude and self-directed learning skills. Asia Pacific Education Review, 17(1), 73-86.

Hytti, U. and O'Gorman, C. (2004). What is 'Enterprise Education'? An Analysis of the Objectives and Methods of Enterprise Education Programmes in Four European Countries. Education ve Training, 46(1), $11-23$.

Iwasiw, C. I. (1987). The role of the teacher in self-directed learning. Nurse Education Today, 7(5), 222-227.

İlhan, E., Kalayc1, N. ve Demir, F. (2018). Endüstri 4.0 doğrultusunda üniversite öğrencilerine kazandırılması amaçlanan temel nitelikler için eğitim programı 4.0. EDUCCON 2018. 27-28 Eylül 2018, Ankara.

James, R. F., and James, M. L. (2004). Teaching career and technical skills in a "mini" business world. Business Education Forum, 59(2), 39-41.

Jaschik, S. (2015, January 20). Study finds big gaps between student and employer perceptions. 22 Ocak $2018 \quad \underline{\text { https://www.insidehigh- }}$ ered.com/news/2015/01/20/study-finds-big-gaps-between-studentand-employer-perceptions adresinden erişildi. 
Johnston, S., and McGregor, H. (2004). Recognising and supporting a scholarship of practice: Soft skills are hard! Creating Flexible Learning Environments:Proceedings of the 15th Australasian Conference for the Australasian Association for Engineering Education and the 10th Australasian Women in Engineering Forum. AustralasianAssociation for Engineering Education.

Kantek, F., Öztürk, N. ve Gezer, N. (2010). Bir sağlık yüksekokulunda öğrencilerin eleştirel düşünme ve problem çözme becerilerinin incelenmesi, International Conference on New Trends in Education and Their Implications, 11-13 Kasım 2010, 186-190, Antalya.

Karataş, K. (2017). Öğretmen adaylarının öz yönetimli öğrenmeye hazırbulunuşluk düzeylerinin üst-bilişsel farkındalık düzeyleri açısından yordanması. Hacettepe Üniversitesi Eğitim Fakültesi Dergisi, 32(2),451465.

Kechagias, K. (2011). Teaching and assessing soft skills. MASS Project, September.

Kicken, W., Brand-Gruwel, S., and Van Merrienboer, J. J. G. (2008). Scaffolding advice on task selection: A safe path toward self-directed learning in on-demand education. Journal of Vocational Education and Training, 60, 223-239.

Klaus, P. (2010). Communication breakdown.California Job Journal, 28, 1-9.

Knowles, M. (1975). Self-directed learning. New York: Association.

Knowles, M. (1984). The adult learner: A neglected species (3rd Ed.). Houston, TX: Gulf.

Krueger, R. (2007). Strategies for Student Engagement: A Case Study from WPI. Presentation at the Polytechnic of Namibia.

Laskey, M. L. and Hetzel, C. J. (2010). Self-regulated learning, metacognition, and soft skills: the 21st century learner. Online Submission. 20 Şubat 2018 https://eric.ed.gov/?id=ED511589 adresinden erişildi.

Leveson, L. (2000). Disparities in perceptions of generic skills: academics and employers. Industry and Higher Education, 14(3), 157-164.

Lincoln, Y. S., and Guba, E. G. (1986). But is it rigorous? Trustworthiness and authenticity in naturalistic evaluation. New directions for evaluation, 30, 73-84. 
Long, H. B. (1991). College students' self-directed learning readiness and educational achievement. In (H. B. Long ve Associates Eds.), Self-directed learning: Consensus and conflict (p.107-122). Oklahoma, OK:Oklahoma Research Center for Continuing Professional and Higher Education of The University of Oklahoma.

Long, H. B. (2000). Understanding self-direction in learning. In ( H. B. Long and Associates Eds.), Practice ve theory in self-directed learning (p.1124). Schaumberg, IL: Motorola University.

Mayes, T. (2009). Overview of the enhancement theme 2006-08: The aims, themes and challenges. Mansfield: The Quality Assurance Agency for Higher Education.

Merriam, S. B. ve Caffarella, R. S. (1999). Learning in adulthood: A comprehensive guide (2nd ed.). San Francisco: Jossey-Bass.

Merriam, S. B. (2001). Andragogy and self-directed learning: Pillars of adult learning theory. The New Update on Adult Learning Theory, 89(Special Issue), 3-14.

Miles, M. B., and Huberman, A. M. (1994). An Expanded Sourcebook: Qualitative Data Analysis (2nd Ed.). Thousand Oaks, CA: SAGE Publications, Inc.

Mourshed, M., Farrell, D., ve Barton, D. (2012). Education to employment: Designing a system that works. (n.p.): McKinsey Center for Government. 25 Ocak 2018 tarihinde https://www.creativitycultureeducation.org/publication/education-to-employment-designing-a-systemthat-works/ adresinden erişildi.

Muller, K., E. (2007). Emotional intelligence and self-directed learning. Unpublished doctoral dissertation, Florida Atlantic University, Florida.

Murnane, R. J., and Levy, F. (1996). Teaching the new basic skills principles for educating children to thrive in a changing economy. New York Free.

Nasri, N. M. (2017). Self-directed learning through the eyes of teacher educators, Kasetsart Journal of Social Sciences. 1-18. http://dx.doi.org/10.1016/j.kjss.2017.08.006

National Association of Colleges and Employers' (NACE). (2009). Experiential education survey. 24 Ocak 2018 tarihinde https://www.immagic.com/eLibrary/ARCHIVES/GEN-

ERAL/NACE US/N090318E.pdf adresinden erişildi.

Nussbaum, M.C. (2010). Not For Profit. Why democracy needs the humanities. USA: Princeton University. 
ODEP. [Office of Disability Employment Policy]. (2007). Soft Skills to Pay the Bills MasteringSoft Skills for Workplace Success. 15 Ocak 2018 tarihinde http://www.dol.gov/odep/topics/youth/softskills/ adresinden erişildi.

OECD. (2016). Getting skills right:Assessing and anticipating changing skill needs. 15 Ocak 2018 http://www.oecd.org/els/getting-skills-rightassessing-and-anticipating-changing-skill-needs-9789264252073en.htm adresinden erişildi.

Orakc1, S. ve Gelisli, Y. (2019). The effect of the application of learning activities based on learner autonomy on the 6th grade students' English achievements, attitudes and learner autonomy. International Journal of Curriculum and Instruction, 11(1), 269-292.

Pautasso, M. (2013). Ten simple rules for writing a literature review. PLoS Computational Biology, 9(7), 1-4, https://doi.org/10.1371/journal.pcbi.1003149

Percival, A. (1996). Invited Reaction: An Adult Educator Responds. Human Resource Development Quarterly, 7(2), 131-139.

Philipose, L. (2010). Germany: Hard facts about soft skills in universities. 16 Ocak 2018 http://www.universityworldnews.com/article.php?story $=20101002085623288$ adresinden erişildi.

Programme for the International Assessment of Adult Competencies. (2016). Survey of adult skills. 16 Ocak 2018 http://www.oecd.org/skills/piaac/ adresinden erişildi.

Puncreobutr, R. (2016). Education 4.0: New challenge of learning. St. Teresa Journal of Humanities and Social Sciences, 2(2), 92-97.

Purdue University Center for Career Opportunities [PUCCO]. (2002, October). Soft skills: A key to employment today. Career Opportunities News, 20, 2. 16 Ocak 2018 https://www.cco.purdue.edu/Articles/Article-SoftSkills.shtml adresinden erişildi.

Roberson, D. N. (2005). Self-directed learning-Past and present. 18 Ocak 2018 https://files.eric.ed.gov/fulltext/ED490435.pdf

Roberts, D. G. (1986). A study of the use of the self-directed learning readiness scale as related to selected organization variables. Unpublished doctoral dissertation, The George Washington University, Washington.

Robles, M. M. (2012). Executive perceptions of the top 10 soft skills needed in today's workplace. Business Communication Quarterly, 75(4), 453-465. 
Russell, J., Russell, B., and Tastle, W. J. (2005). Teaching soft skills in a systems development capstone class. Information Systems Journal, 3(19), 1-23.

Saks, K., and Leijen, A. (2014). Distinguishing self-directed and self- regulated learning and measuring them in the e-learning context. Procedia Social and Behavioural Sciences, 112,190-198.

Salmi, J. (2009). Dünya çapında üniversiteler kurmanın zorluğu (K. Yamaç, Çev.) Ankara: Eflatun.

Saracaloğlu, S., Yenice, N., ve Karasakaloğlu, N. (2009). Öğretmen adaylarının iletişim ve problem çözme becerileri ile okuma ilgi ve alışkanlıkları arasındaki ilişki. Yüzüncü Yıl Üniversitesi Ĕ̆itim Fakültesi Dergisi, 6(2), 167-185.

Sarmasoğlu, Ş. ve Görgülü, S. (2014). Self-directed learning readiness levels of nursing students. Hacettepe Üniversitesi Hemşirelik Fakültesi Dergisi, $1(3), 13-25$.

Schulz, B. (2008). The importance of soft skills: Education beyond academic knowledge. Nawa Journal of Communication, 2(1), 146-154.

Senge, P. (1992). The fifth discipline fieldbook. New York: Doubleday/Currency. Skills for College and Career Readiness. (2016). Employability skills. 20 Ocak 2019 tarihinde http://cte.ed.gov/employabilityskills/ adresinden erişildi.

Slevin, D., and Lavery, M. (1991). Self-directed learning and student supervision. Nurse Education Today, 11, 368-377.

Smith, M. K. (2002). Malcolm Knowles, informal adult education, self-direction andandragogy. Encyclopedia of informal education. 20 Ocak 2019 tarihinde www.infed.org/thinkers/et-knowl.htm adresinden erişildi.

Spencer, J. A., ve Jordan, R. K. (1999). Learner centred approaches in medical education. British Medical Journal, 318, 1280-1283.

Suknaisith, A. (2014). The results of self-directed learning for project evaluation skills of undergraduate students.Procedia- Social and Behavioral Sciences, 116, 1676-1682.

Taylor, B. (1995). Self-directed learning: Revisiting an idea most appropriate for middle school students. Paper presented at the Combined Meeting of the Great Lakes and Southeast International Reading Association, Nashville, TN, Nov 11-15. [ED395287]

Taylor, E. (2016). Investigating the perception of stakeholders on soft skills development of students: Evidence from South Africa.Interdisciplinary journal of e-skills and lifelong learning, 12, 1-18. 
Tobin, D. R. (2000). All learning is self-directed: How organizations can support and encourage independent learning. Alexandria, VA: American Society for Training and Development.

Tough. A. (1979). The adult's learning projects: A fresh approach to theory and practice in adult learning. (2nd ed.). Toronto: The Ontario Institute for Studies in Education.

Urs Sorana, D. (2013). Soft skills for the engineering students. Synergy, 9(2), $137-142$.

Üstün, A. (2012). Cinsiyete göre öğrencilerin kullandıkları bilişsel ve bilişüstü öz düzenleme stratejilerinin akademik başarıları üzerindeki etkileri. Yayınlanmamış yüksek lisans tezi, Çanakkale Onsekiz Mart Üniversitesi, Çanakkale.

Vardar, A. K. (2011). Öz-düzenleme stratejileri öğretiminin, öğrencilerin İngilizce başarılarına, öz-düzenleme stratejileri kullanımına ve tutumlarına etkisi. Yayınlanmamış doktora tezi, Abant İzzet Baysal Üniversitesi, Bolu.

Wheeler, R. E. (2016, January/February). Soft skills-the importance of cultivating emotional intelligence (AALL Spectrum). Boston, MA: Boston University School of Law.

Whiteside, M., Bould, E., Tsey, K., Venville, A., Cadet-James, Y., ve Meg E. M. (2017). Promoting twenty-first-century student competencies: A wellbeing approach. Australian Social Work, 70(3), 324-336. doi:10.1080/0312407X.2016.1263351

Wiek, A., Withycombe, L., and Redman, C. L. (2011). Key competencies in sustainability: A reference framework for academic program development. Sustainability Science, 6,203-218. doi:10.1007/s11625011-01326

Wilhelm, W. J., Logan, J., Smith, S. M., and Szul, L. F. (2002). Meeting the demand: Teaching "soft" skills. $15 \quad$ Ocak 2018 https://files.eric.ed.gov/fulltext/ED477252.pdf adresinden erişildi.

Wynekoop, J., and Walz, D. (2000). Investigating traits of top performing software developers. Information Technology ve People,13, 186-195.

Yan, L.,Yinghong, Y., Lui, S.M., Whiteside, M., and Tsey, K. (2018). Teaching "soft skills" to university students in China: The feasibility of an Australian approach.Educational Studies, DOI: 10.1080/03055698.2018. 1446328

Yıldırım, A. ve Şimşek, H. (2013). Sosyal Bilimlerde Nitel Araştırma Yöntemleri (9. Bask1). Ankara: Seçkin. 
Yu, C. (1998). A study of the relationship between the self-directed learning readiness and job performance for high school principals. Yayınlanmamış Doktora Tezi, Ohio State University, Ohio.

Yuan, H. B., Wiliams, B. A., Fang, J. B., and Pang, D., (2012). Chinese baccalaureate nursing students' readiness for self- directed learning. Nurse Education Today, 32, 427-431.

\section{Kaynakça Bilgisi / Citation Information}

Şimşek, H. ve İlhan, E. (2019). Yükseköğretimde insani becerilerin öğrenenlere kazandırılması için öz yönelimli öğrenme modeli. OPUS-Uluslararası Toplum Araştırmaları Dergisi, 14(20), 1896-1935. DOI: 10.26466/opus.595168 